\title{
Prostaglandin E2 and Cancer: Insight into Tumor Progression and Immunity
}

\author{
Federica Finetti ${ }^{1, *},+\mathbb{C}$, Cristina Travelli ${ }^{2,+} \oplus$, Jasmine Ercoli ${ }^{1}$, Giorgia Colombo ${ }^{3}$, Erica Buoso ${ }^{2} \mathbb{C}$ \\ and Lorenza Trabalzini ${ }^{1, *(D)}$ \\ 1 Department of Biotechnology, Chemistry and Pharmacy, University of Siena, 53100 Siena, Italy; \\ ercoli3@student.unisi.it \\ 2 Department of Pharmaceutical Sciences, University of Pavia, 27100 Pavia, Italy; \\ cristina.travelli@unipv.it (C.T.); erica.buoso@unipv.it (E.B.) \\ 3 Department of Pharmaceutical Sciences, University of Piemonte Orientale, 28100 Novara, Italy; \\ giorgia.colombo@uniupo.it \\ * Correspondence: finetti2@unisi.it (F.F.); lorenza.trabalzini@unisi.it (L.T.) \\ + These authors contributed equally to the work.
}

Received: 30 October 2020; Accepted: 29 November 2020; Published: 1 December 2020

Simple Summary: Inflammation is assessed as a hallmark of cancer and it is now widely recognized that there exists a direct causal link between inflammation and tumors. Among the inflammatory mediators, prostaglandin E2 (PGE2), the major product of cyclooxygenases (COXs), plays a pivotal role in tumor progression. Numerous pieces of evidence suggest that drugs, such as aspirin and non-steroidal anti-inflammatory drugs (NSAIDs) that inhibit PGE2 production, may exert a protective effect against tumor initiation and may play a role during tumor progression. In fact, a number of studies suggest that PGE2 increases tumor growth and invasion, reduces apoptosis, increases metastasis and angiogenesis, and suppresses antitumor immunity. In this review, we describe the current knowledge on the pro-tumoral activity of PGE2 focusing on its role in cancer progression and in the regulation of the tumor microenvironment.

Abstract: The involvement of inflammation in cancer progression has been the subject of research for many years. Inflammatory milieu and immune response are associated with cancer progression and recurrence. In different types of tumors, growth and metastatic phenotype characterized by the epithelial mesenchymal transition (EMT) process, stemness, and angiogenesis, are increasingly associated with intrinsic or extrinsic inflammation. Among the inflammatory mediators, prostaglandin E2 (PGE2) supports epithelial tumor aggressiveness by several mechanisms, including growth promotion, escape from apoptosis, transactivation of tyrosine kinase growth factor receptors, and induction of angiogenesis. Moreover, PGE2 is an important player in the tumor microenvironment, where it suppresses antitumor immunity and regulates tumor immune evasion, leading to increased tumoral progression. In this review, we describe the current knowledge on the pro-tumoral activity of PGE2 focusing on its role in cancer progression and in the regulation of the tumor microenvironment.

Keywords: prostaglandin E2; tumor inflammation; angiogenesis; metastasis; EP receptor; tumor microenvironment; cancer-related inflammation; immunosuppression

\section{Introduction}

The involvement of inflammation in cancer progression was first described in 1863 by Rudolf Virchow. He observed that infiltrated immune cells reflect the place where cancer lesions appear in the 
inflamed tissue and hypothesized that chronic inflammation is a condition that predisposes one to cancer development. Most recent observations revealed that there is a direct causal link between inflammation and cancer: it is estimated that primary infections (such as Helicobacter pylori, hepatitis B and C viruses) and inflammatory responses are linked to $7 \%$ to $30 \%$ of cancer deaths worldwide [1,2]. Consistently, epidemiological observation showed that daily aspirin or other non-steroidal anti-inflammatory drugs (NSAIDs) reduced deaths due to several common cancers [3-7], indicating that cyclooxygenase (COX) inhibition and the reduction of its main metabolic product, prostaglandin E2 (PGE2), may prevent solid-organ cancers.

\section{Prostaglandin E2 Biosynthesis and Functions}

Several biological activities have been attributed to PGE2 both in physiological and pathological conditions. In physiological processes, PGE2 regulates fever, kidney function, pain, mucosal integrity, blood vessel homeostasis, and inflammation. In pathological conditions, as in cancer, PGE2 is produced by cancerous stromal cells and enhances tumor cell proliferation and survival, promotes angiogenesis, and induces metastasis. During tumor progression, PGE2 exerts its activity through ligation with four E-type prostanoid (EP) receptors 1-4 (EP 1-4), by acting on releasing cells (autocrine mechanism) and neighboring cells (paracrine mechanism) [8].

PGE2 belongs to the prostanoid family of lipids, a subclass of eicosanoids produced by oxidation of 20-carbon essential fatty acids that are localized within cell membranes. Prostanoids are synthesized by sequential actions of different and highly specific enzymes. Their synthesis is initiated after the release of arachidonic acid (AA) from membrane lipids by phospholipases A2 (PLA2) family members.

Membrane-released AA is rapidly oxidized into the unstable metabolite, prostaglandin G2 (PGG2), which is subsequently reduced to PGH2. Both steps are sequentially catalyzed by the COX enzymes. COX-1 is constitutively expressed at basal levels in many cells, generating low levels of PGs that are cytoprotective and maintain body homeostasis. In contrast, COX-2 is normally absent in most cells and it is induced in response to a variety of stimuli including growth factors and cytokines [9-11]. Once synthesized, PGH2 is rapidly converted into PGE2 by three distinct terminal synthases (Figure 1).

These synthases include microsomal PGE synthase-1 (mPGES-1), mPGES-2, and cytosolic PGE synthase (cPGES) and are tightly regulated under various conditions. mPGES- 1 is frequently induced concomitantly with COX-2 by several proinflammatory stimuli to generate a transient increase of PGE2 levels [12,13]. The levels of PGE2 can also be regulated by its metabolic turnover. The activation of two key catabolic enzymes, 15-hydroxyprostaglandin dehydrogenase (15-PGDH) and 15-ketoprostaglandin-13-reductase (13-PGR), can essentially eliminate the biological activity of PGE2 [14].

Following synthesis, the physiological activity of PGE2 is mediated by the activation of downstream signaling cascades via seven transmembrane G-protein coupled receptors (GPCRs), referred as the EP receptors. The EP receptor family consists of four isoforms (EP1-4) coupled to heterotrimeric G

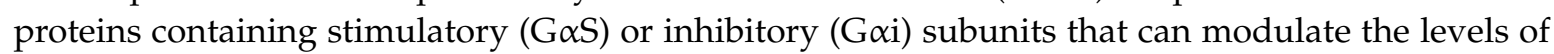
$\mathrm{Ca} 2+$, cyclic AMP (cAMP), and inositol phosphate, thus, activating divergent downstream signaling pathways [15] (Figure 1). The interaction between PGE2 and EP receptors is dependent on cell and tissue type and location. On cancer cells, the expression and localization of EP receptors may be variable and may influence cell response to PGE2. Specific effects depending on the activation of the different EP receptor subtype have been described, including EP1-dependent tumor cell migration and invasion, EP2-induced angiogenesis and suppression of the anti-tumor immune response, and, finally, EP4-related tumor cell migration and metastasis. The role of the EP3 receptor has yet to be clarified [15]. 


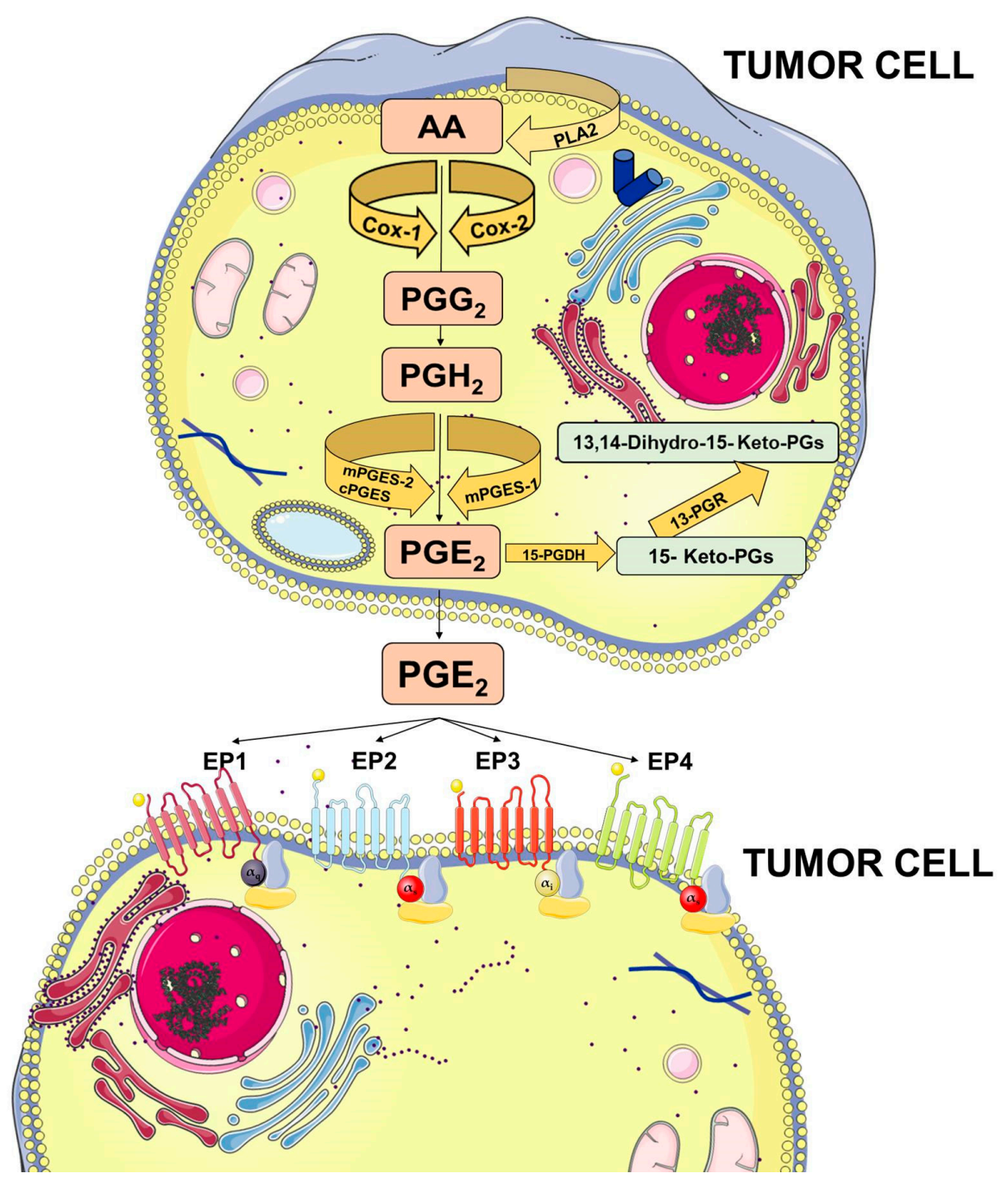

Figure 1. Prostaglandin E2 (PGE2) biosynthesis. Arachidonic acid (AA) is a polyunsaturated fatty acid that constitutes the phospholipid domain of most cell membranes and is released from the cellular membranes by cytoplasmic phospholipases A2 (PLA2). Free AA can be metabolized to PGE2 through the cyclooxygenase (COX) pathway. In this pathway, the key step is the enzymatic conversion of AA to the intermediate prostaglandin G2 (PGG2), which is then reduced to the intermediate PGH2 by the peroxidase activity of COX. PGH2 is sequentially metabolized to PGE2 by specific PGE synthases (cytosolic PGE synthase (cPGES), microsomal PGE synthase-1 (mPGES1), and mPGES2). PGE2 exerts its effects through ligation with four G-protein-coupled receptors (GPCRs), EP1-EP4. Each E-type prostanoid (EP) receptor couples to distinct signaling pathways. This figure was created using Servier Medical Art templates, which are licensed under a Creative Commons Attribution 3.0 Unported License; https://smart.servier.com.

\section{Prostaglandin E2 and Cancer}

PGE2 is the most abundant prostaglandin that has been found in various human malignancies. Inhibition of its production by unselective COX inhibitors such as aspirin or other NSAIDs have been associated with a reduced risk of colon, breast, lung, prostate, and other solid cancers and their recurrence (see Table 1) [16-18]. Furthermore, it has been reported that COX-2 and/or mPGES-1 are constitutively expressed in several cancers, including non-small cell lung cancer $[19,20]$, colorectal cancer [21,22], breast cancer [23,24], prostate cancer [25,26], melanoma [27], and hepatocellular carcinoma [28,29], suggesting that the COX-2/mPGES-1/PGE2 pathway is linked to the neoplastic progression. To outline the importance of this pathway, several efforts have been conducted to develop 
selective COX-2 inhibitors lacking the side effects of unselective COX inhibitors and provided with specific activities [30]. Among these, celecoxib showed antitumoral activity (see Table 1), being able to reduce the risk of colon, breast, prostate, and lung cancer [31]. However, long-term consumption of COX-2 inhibitors presents important side effects [30] and their use as anticancer agents has to be better investigated.

Table 1. Studies related to the role of aspirin and other non-steroidal anti-inflammatory drugs (NSAIDs) in cancer.

\begin{tabular}{ccc}
\hline NSAID & Cancer & References \\
\hline & Colorectal cancer & {$[3,18,32-45]$} \\
\cline { 2 - 3 } & Breast cancer & {$[17,41,46-51]$} \\
\cline { 2 - 3 } Aspirin & Lung cancer & {$[52-60]$} \\
\cline { 2 - 3 } & Prostate cancer & {$[3,37,38,43,61]$} \\
\cline { 2 - 3 } & Ovarian cancer & {$[3,62]$} \\
\cline { 2 - 3 } & Gastric cancer & {$[37,63-65]$} \\
\cline { 2 - 3 } & Breast cancer & {$[3,37,66-70]$} \\
\hline \multirow{2}{*}{ Coxib } & Colon cancer & {$[31,71-76]$} \\
& Prostate cancer & {$[31,76,76-79]$} \\
& Lung cancer & {$[31,76]$} \\
\hline
\end{tabular}

Several animal models have been developed and used to assess the efficacy of COX inhibition in vivo by using low-dose aspirin or NSAIDs, and to elucidate the molecular mechanisms of PGE2-induced tumor progression.

A large number of studies have been conducted to reveal the role of PGE2 in colon cancer carcinogenesis and progression. For example, regression of small intestinal adenomas in ApcMin/+ mice induced by NSAIDs is blocked by PGE2 treatment [84]. Moreover, the adenoma-preventive activity of celecoxib is abrogated in 15-PGDH KO mice that possess increased endogenous PGE2 levels [85]. Genetic deletion of 15-PGDH increases endogenous PGE2 levels and promotes colon tumor growth also in ApcMin/+ and azoxymethane (AOM) mouse models [86]. In addition, intraperitoneal PGE2 treatment boosts the AOM-induced colon tumor incidence and multiplicity and significantly increases proliferative index and reduces apoptotic index [87]. Likewise, it has been demonstrated in three different mouse models of intestinal tumorigenesis that chronic low-dose aspirin prevents tumor formation and that the aspirin antitumor effect is most pronounced when treatment is started before tumor initiation [88].

To further outline the important role of PGE2 in colon carcinogenesis, different studies showed that mPGES-1 deletion suppresses the development of intestinal tumors in ApcMin/+ and AOM models [89,90]. Moreover, Sasaki et al. have reported that mPGES-1 deletion reduces AOM-induced colon polyp and aberrant crypt foci (ACF) formation [91]. Similar results were reported in animal models of breast cancer [92].

Additional information regarding the role of PGE2 signaling has been obtained from xenograft animal models, in which reduction of PGE2 production results in decreased tumor growth $[15,26,93,94]$.

\section{Molecular Mechanisms Linking PGE2 and Tumor Progression}

Inflammation has been reported as one of the hallmarks of cancer, due to its capability to supply bioactive molecules that promote cancer proliferation, invasion, and metastasis; limit cell apoptosis; and induce the angiogenic process [95]. Molecular and cellular inflammatory pathways that sustain cancer progression have been identified and are reported as intrinsic and extrinsic 
inflammatory pathways [96,97]. In the intrinsic pathway, genetic events that are able to induce neoplastic transformation promote the expression of inflammatory mediators that guide the construction of an inflammatory microenvironment and sustain tumor progression processes. Instead, the extrinsic pathway is driven by inflammatory leukocytes and soluble mediators that establish inflammatory conditions that increase cancer risk [96]. The upregulation of the COX-2/mPGES-1/PGE2 axis appears to be fundamental for both processes. In this review, we will provide a detailed overview of the principal molecular pathways activated by PGE2 (Figure 2).

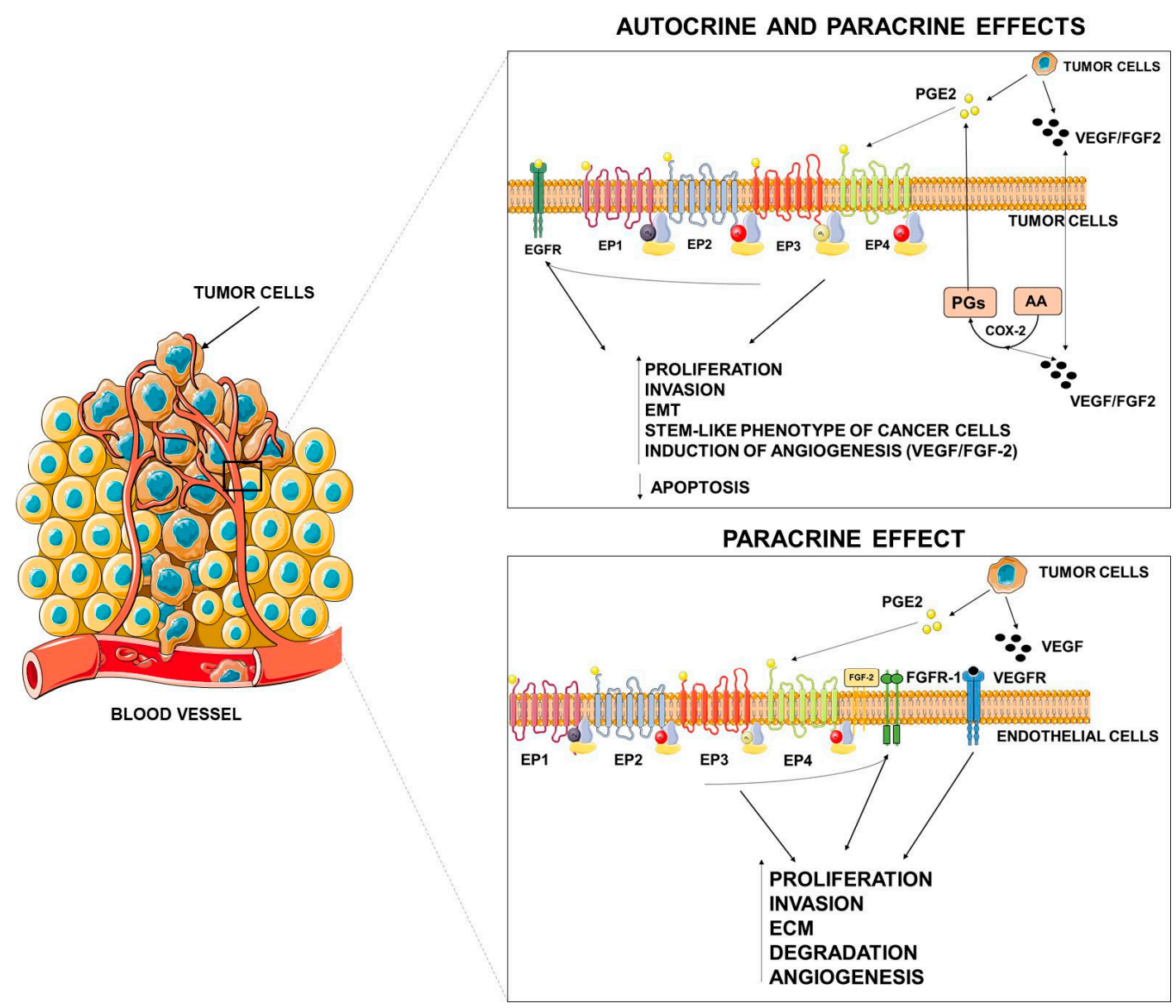

Figure 2. Autocrine and paracrine effects of PGE2. PGE2, released by tumor cells, may elicit autocrine and paracrine effects on tumor or stromal cells either by specific activation of its receptors or by tyrosine kinase $(\mathrm{TK})$ receptor transactivation. VEGF = vascular endothelial growth factor, FGF = fibroblast growth factor, EMT = epithelial mesenchymal transition, ECM = extracellular matrix. This figure was created using Servier Medical Art templates, which are licensed under a Creative Commons Attribution 3.0 Unported License; https://smart.servier.com.

As occurs in extrinsic inflammation, an increasingly large body of evidence indicates that PGE2 promotes tumor growth through autocrine and paracrine mechanisms by activating EP receptors present both in cancer cells and in stromal cells and by transactivating growth factor receptor tyrosine kinases (RTKs) frequently upregulated in cancer cells $[15,98]$. EP receptors activate a range of intracellular signaling pathways that mediate the effects of PGE2 on cell functions.

The EP1 receptor is coupled to the G $\alpha$ q protein subunit that is linked to phosphoinositide-PLC activation. This signaling leads to an increase of intracellular Ca2+ and PKC activation that finally induce gene transcription through the activation of nuclear factor of activated $\mathrm{T}$ cells (NFAT), nuclear factor-kappaB (NFkB), and the MAPK pathways [99]. 
The involvement of the EP1 receptor in cancer has been documented by several reports showing that EP1 signaling inhibition obtained by selective antagonists or by $\mathrm{KO}$ mice reduce the number of azoxymethane-induced aberrant crypt foci formation [100-102]. Consistently, EP1 receptor antagonists inhibit polyp formation in APC KO mice [103], decrease the number of UVB-induced skin tumors in mice [104], and diminish the incidence of tongue cancer in rats [105].

Instead, both the EP2 and EP4 receptors are linked to G $\alpha$ s proteins that activate adenylate cyclase and generate cAMP which in turn activates the protein kinase A (PKA) pathway [106]. EP2 and EP4 receptors also mediate glycogen synthase kinase $3 \beta$ (GSK3 $\beta$ ) $-\beta$ catenin pathways. PGE2 is able to promote colon cancer cell growth through EP2 signaling that involves the activation of phosphoinositide 3-kinase (PI3K) and the protein kinase Akt and the inactivation and release of GSK3 $\beta$ from its complex with axin, thereby activating the $\beta$-catenin signaling pathway [107]. Moreover, in similar models of colon cancer cells, PGE2 induces CREB phosphorylation by the PKA pathway and regulates $\beta$-catenin and cyclin D1 cellular localization via EP2 and EP4 receptors [108]. In addition, Akt pathway activation promoted by EP4 receptor results in the activation of mTORC1 [109]. Several other studies have shown that EP2 and EP4 induce the activation of multiple signaling cascades that are associated with squamous cell carcinoma (SCC) [110,111]; human hepatocellular carcinoma (HCC) [112]; glioma [113]; prostate [114], bladder [115], endometrial [116], and breast cancer [117] cell growth.

By using EP2 receptor KO mice, it has been demonstrated that the EP2 receptor controls the progression of lung [118], skin [119,120], and breast [121,122] cancer. Moreover, genetic ablation of the EP2 or EP4 receptors also decrease both the size and number of intestinal polyps in APC mice [123,124]. Moreover, the inhibition of the EP4 receptor with either AH23848 or ONO-AE3-208 reduces metastasis in breast cancer models [125].

The human EP3 gene consists of ten exons and nine introns, encoding at least eight distinct EP3 splice variants [126]. This could partially explain the different effects of EP3 in different tumors. The EP3 receptor is able to couple with a number of G-protein subunits including Gi, Gs, and G13, thus, stimulating or inhibiting adenylyl cyclase (AC), as well as stimulating Ca2+ mobilization, possibly via PLC. The major EP3 splice variant is thought to be coupled to an inhibitory (Gi) protein. Therefore, the primary outcome of EP3 receptor signaling is inhibition of AC and activation of the Ras/Raf and MAPK signaling pathway $[106,127,128]$. EP3 has been reported to mediate the carcinogenesis in numerous tumors with conflicting effects [15].

In addition to the canonical activation of EP receptors, PGE2 has been shown to promote cancer progression through the interaction with oncogenic signals, including epidermal growth factor (EGF) and its receptor (EGFR) [26,110,129-132]. In particular, PGE2 and EGF/EGFR may cooperate to promote growth, invasion, epithelial mesenchymal transition (EMT), and a stem-like phenotype of cancer cells $[110,130,131,133]$. It was also demonstrated that EGF induces the upregulation of mPGES-1 expression and PGE2 production, and that mPGES-1 inhibition significantly reduces the EGF-mediated tumorigenicity $[26,93,134]$, indicating a cooperative loop between the two signaling pathways.

\section{PGE2 and Angiogenesis}

Numerous in vitro and in vivo studies have indicated that the COX-2/mPGES-1/PGE2 pathway plays a pivotal role in promoting the angiogenic switch in cancer (Figure 2) [11]. COX-2/mPGES-1 overexpression in tumor cells has been reported to promote the production of angiogenic factors such as vascular endothelial growth factor (VEGF) and fibroblast growth factor (FGF-2) [11].

In cancer cells, PGE2 stimulates VEGF expression through several mechanisms including the activation of the hypoxia inducible factor- $1 \alpha$ (HIF-1 $\alpha)$ [135,136] or the cAMP signaling pathway [137]. Similarly, mPGES-1/PGE2 drive the angiogenic phenotype of cancer cells through the Dicer downregulation, and the subsequent PGE2-mediated downregulation of miR-15a and miR-186 that appear to be specifically related to VEGF production [138]. PGE2 can also induce VEGF secretion through the transactivation of EGFR mediated by EP2 and EP4 receptors [139-141]. Similarly, PGE2 can 
activate EP2-mediated FGF2 expression in endometrial adenocarcinoma cells through the activation of PKA, Src, EGFR, and ERK1/2 signaling [142].

Intriguingly, VEGF and FGF2 induce COX-2 expression and PGE2 production in endothelial cells. These data suggest that the effects of PGE2 on regulation of VEGF and FGF2 are probably amplified through a positive feedback loop [143,144].

In animal models, the EP2 receptor that controls the number and size of intestinal polyps in Apc (Delta 716) mice increases cellular cAMP and stimulates the expression of COX-2 and VEGF in the polyp stroma, demonstrating that PGE2 induction of VEGF is important for tumor growth in vivo [123]. Similar data have been reported also for breast cancer [122].

In addition to direct effects elicited by cancer-produced PGE2 on cancer and endothelial cells (autocrine/paracrine actions), several observations reported that PGE2 produced by stromal cells and present in the microenvironment may affect tumor niche to promote tumor progression. PGE2 signaling appears as a node of chronic inflammation which shapes the tumor microenvironment $[145,146]$.

For example, PGE2 signaling in stromal cells also contributes to angiogenesis. A host PGE2-EP2 signal is required for tumor angiogenesis by enhancing endothelial cell motility and vascular hyperpermeability, as demonstrated in a mouse model of breast cancer in which the deletion of the EP2 receptor impairs tumor angiogenesis [147]. Similarly, the host PGE2-EP3 signal is a prerequisite for tumor-stromal angiogenesis that was markedly suppressed in mice EP3-/- and was linked to a reduced expression of VEGF [148].

PGE2 can also directly act on endothelial cells to promote a pro-angiogenic phenotype through the activation of fibroblast growth factor receptor-1 (FGFR1) signaling [149]. Indeed, it was reported that PGE2 synergizes with fibroblast growth factor 2 (FGF2) and induces the endothelial autocrine/paracrine FGF2/FGFR1 signaling through upregulation of FGF2 expression and its mobilization from the extracellular matrix [150]. In this context, PGE2 acts as a primer of the angiogenic switch by promoting the activation of the FGF2/FGFR1 system by multiple mechanisms [149,150].

Given the pivotal role played by the microenvironment in tumor metastasis, some observations are available on the possible molecular processes by which the primary tumor controls the pre-metastatic niche in the secondary site prior to the formation of metastasis. Liu et al. have determined that primary tumor-derived VEGF tumors can alter the lung microenvironment through PGE2 production in a model of breast cancer, leading circulating tumor cells to localize preferentially in these regions [151]. Similarly, PGE2 appears to regulate tumor metastasis in non-small-cell lung cancer (NSCLC) [152], colorectal cancer [153,154], breast cancer [155], and hypopharyngeal squamous cell carcinoma [156].

\section{PGE2 and Its Roles in the Regulation of the Tumor Microenvironment}

It is now well accepted that a typical hallmark of tumors is an important immunosuppressive niche composed of suppressive immune cells which play a major role in the regulation of tumor progression, supporting cancer stemness and helping the tumor in the metastatic process. In the last decade, therapeutic strategies targeting these cellular populations have been developed and found to be beneficial in clinical practice (e.g., anti-PD1 and anti-CTLA4 therapies) [157]. The immune subsets that orchestrate tumor immunosuppression include myeloid-derived suppressor cells (MDSCs), tumor-associated macrophages (TAMs), dendritic cells (DCs), natural killer (NK) T cells, and regulatory T-cells (Tregs). Herein, as depicted in Figure 3, the major roles of PGE2 in the fine regulation of these cells are summarized, with the aim of immunoregulation. 


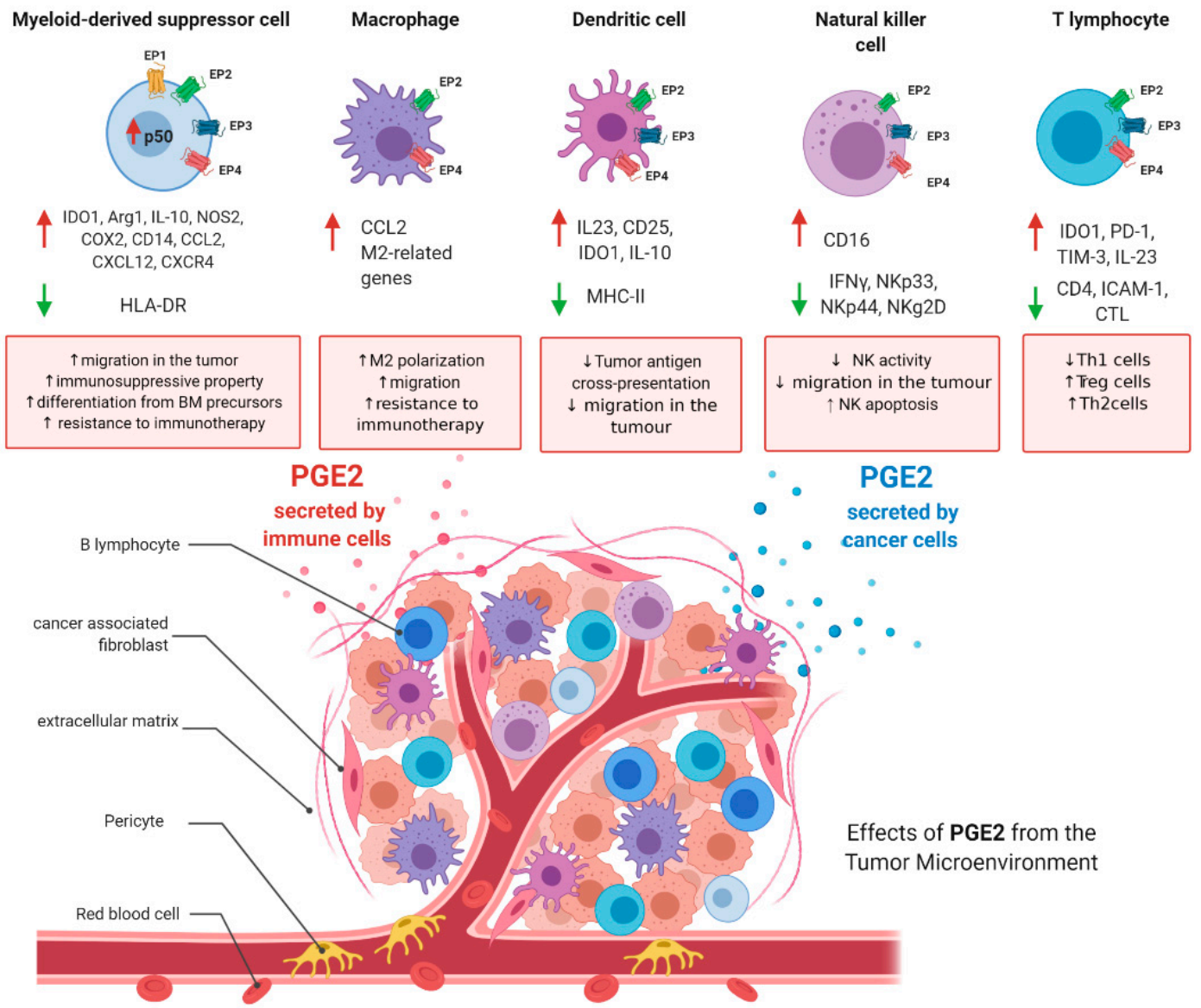

Figure 3. PGE2 roles in immunosuppressive tumoral niche. PGE2 levels are increased in the tumoral microenvironment. PGE2 is secreted by cancer cells and immune cells. In the figure are depicted the main functions of PGE2 in myeloid-derived suppressor cells, tumor-associated macrophages, dendritic cells, natural killer (NK) cells, and T-cells. Figure has been generated using BioRender.

\subsection{PGE2 and Myeloid-Derived Suppressor Cells}

Myeloid-derived suppressor cells (MDSCs) are a heterogeneous population of immature myeloid cells, enriched in cancers, with a crucial role in the maintenance of an immunosuppressive microenvironment [158]. Physiologically, in the bone marrow (BM), the hematopoietic stem cells (HSCs) give rise to immature myeloid cells (IMCs) which differentiate into mature myeloid cells. In the context of cancer, the tumor microenvironment releases mediators/cytokines that determine the development of IMCs to MDSCs. Furthermore, cancer cells secrete different types of chemokines that signal MDSC migration to tumors. MDSCs are schematically subdivided into monocytic-like cells (M-MDSCs) and granulocytic-like cells (PMN-MDSCs). These two subsets of MDSCs share the same ability to suppress adaptive immunity via different mechanisms of action. In brief, MDSCs suppress anti-tumor immunity through multiple mechanisms, including (i) the release of factors able to stimulate Treg activation and differentiation; (ii) the blockade of migration of naïve-T cells to lymphoid organs and the formation of effector T cells; (iii) production of high levels of reactive oxygen species (ROS) and nitric oxide (NO), up-regulating arginase 1 (ARG-1), and inducible nitric oxide synthase/ nucleotide-binding oligomerization domain-containing protein 2 (iNOS/NOD2). Of note, the induction of MDSCs' development can be triggered by several factors including interleukin-1 $\beta$ (IL-1 $\beta$ ), interleukin 10 (IL-10), macrophage-colony stimulating factor (M-CSF), interleukin-6 (IL-6), metabolic enzymes (e.g., NAMPT, indoleamine 2,3-dioxygenase (IDO1)), toll like receptor (TLR)-ligands, or VEGF [158-160]. Importantly, PGE2 has emerged as an important player in MDSC s' activation and migration. 


\subsubsection{PGE2 and MDSCs Differentiation}

The primary role of PGE2 in MDSCs was first characterized by Sinha and collaborators demonstrating how PGE2 controls MDSC differentiation in a preclinical model of mammary carcinoma. They highlighted that PGE2 induces a 3-fold increase in levels of suppressive $\mathrm{Gr}^{+} \mathrm{CD}^{+} 1 \mathrm{~b}^{+}$cells in vitro, therefore, prompting the idea that PGE2 is involved in the differentiation of MDSCs from bone marrow progenitors. Of note, by analyzing spleens of $4 \mathrm{~T} 1$ tumor-bearing mice, they found that MDSCs express all the four receptors for PGE2 (i.e., EP1, EP2, EP3, EP4) [161]. Importantly, using butaprost (EP2 agonist), AH6809 (EP1 and EP2 antagonist), and AH23848 (EP4 antagonist), they clearly demonstrated that PGE2 mediates MDSC differentiation through either the EP1, EP2, and/or EP4 receptors. Using EP2 KO mice they also proved that the ablation of EP2 receptor retards mammary carcinoma growth by reducing MDSC levels, indicating that PGE2 mediates MDSC accumulation also in vivo [161]. Importantly, the treatment with the COX-2 inhibitors (SC58236 and SC58236) delays primary carcinoma tumor burden with an important reduction of MDSCs levels.

In accordance with these findings, it is known that tumor exosomes are taken up by bone marrow myeloid cells and contribute to the development of MDSCs [162]. Furthermore, Xiang et al. demonstrated that the promotion of tumor growth by MDSCs is dependent on tumoral exosomes which are enriched of PGE2. Of note, antibodies against exosomal PGE2 block the activity of these exosomes on MDSCs' induction and attenuate tumor growth in vivo [163]. In agreement with this study, the direct role of PGE2 in the activation of monocyte differentiation has been proven since the stimulation of monocytes with PGE2 induces several immunosuppressive factors leading to MDSC phenotype (e.g., IDO1, Arg1, IL-10, NOS2). Moreover, PGE2 per se induces COX-2 leading to autocrine production of endogenous PGE2 in MDSCs [164]. Obermayer and collaborators discovered a positive feedback loop between PGE2 and COX-2 in the differentiation of monocytes, redirecting to functional differentiation of DCs toward monocytic MDSCs, a mechanism undertaken by cancer cells to locally produce suppressive MDSCs. Alone, the administration in vitro of PGE2 redirects the granulocyte-macrophage colony-stimulating factor (GM-CSF) and IL-4 to the differentiation of dendritic cells toward MDSCs [164,165]. The ability of EP2 and EP4 agonists, but not of EP3/1 agonists, to reproduce PGE2-induced effects demonstrates the key role of EP2 and EP4 in mediating the MDSCs. Of note, Rodriguez-Ubreva et al. studied the comparison between MDSC and DC DNA methylomes and revealed extensive demethylation with specific gains of DNA methylation. In particular, they found that PGE2 leads to highly specific and DNA methyltransferase 3 alpha (DNMT3A)-dependent hypermethylation and downregulation of a subset of myeloid-associated genes. Although the mechanisms by which MDSCs suppress T-cells have been extensively studied, less is known about MDSCs' regulation of NK-cell activity [166]. Direct involvement of PGE2 during the initiation and maintenance of NK-cell suppression by MDSCs has been proven by Mao et al. They demonstrated that PGE2 increases the immature status of monocytes. Indeed, PGE2 increases the expression of CD14, while the expression of HLA-DR is reduced [167]. They found that the co-culture of MDSCs isolated from melanoma patients with NK cells induces interferon (IFN) $\gamma$ release and IL2-activated NK cells. The stimulation with PGE2 suppresses NK-cell responses, TGF $\beta$ production, and the activation of the EP2 or EP4 receptors [167].

\subsubsection{PGE2 and MDSCs Recruitment}

Several reports have suggested a key role of PGE2 in the recruitment of MDSCs in the tumor site. It is well known that the CXCR4-CXCL12 axis is the key pathway involved in the recruitment of MDSCs into the tumor. Obermajer et al. have observed a correlation between the expression of COX-2, CXCL12 concentrations, and the production of PGE2 in ovarian cancer. Importantly, the secretion of CXCL12 in ovarian cancer ascites was hindered by COX-2 inhibitors [164]. They also found that PGE2 induces both CXCL12 production in the ovarian cancer environment and CXCR4 expression in MDSC precursors, therefore, promoting the attraction and retention of MDSCs in the tumor microenvironment [164]. Similarly, in mouse models of glioma, it has been demonstrated 
that treatment with COX-2 inhibitors reduces the PGE2 production which results in a decrease of MDSC-attracting chemokine CCL2 in the tumor. These data suggest that COX-2 blockade hampers the development of MDSCs and their accumulation in the tumor with a CCL2-dependent mechanism [168]. The role of COX-2 and PGE2 in the recruitment of MDSCs has been validated also in lung cancer. The authors demonstrated that cytotoxic T lymphocytes (CTLs) induce tumor cells to secrete PGE2 as a mediator of MDSCs' recruitment into the tumor. Indeed, both the COX-2 inhibitor and the PGE2 neutralizing antibody (2B5) reduce the number of MDSCs recruited by tumor cells [169]. All these data suggest that the chemoattraction of MDSCs by tumor cells is mediated first by the up-regulation of COX-2 and, secondly, by the PGE2 synthesis.

\subsubsection{PGE2 and MDSCs Activation}

Within the tumors, MDSCs are activated and are able to suppress T-cell proliferation, resulting in the impairment of the anti-tumor immunity. Activated MDSCs increase the expression of iNOS/NOD2, arginase, and IDO1 leading to a significant increase of ROS and NO levels and finally to a decrease of T-cells' proliferation [170].

Ochoa et al. have described for the first time that PGE2 secreted into the tumor microenvironment is a signal to increase arginase expression in MDSCs, resulting in the block of T-cells' proliferation [171]. In addition, the Kiessling group found that the axis COX-2/PGE2 is at the basis of the mechanism by which melanoma cells arrest monocytes in an immature stage, similar to the stage of tumor MDSCs, associated with the ability to impair T-cell functions. Indeed, they found that treatment of melanoma-patient-derived monocytes with PGE2 leads to the loss of T-cell proliferation and IFN $\gamma$ production. Of note, the suppression is mediated by the direct activation of monocytes despite $\mathrm{T}$ cells, because PGE2 per se does not affect T-cell proliferation in this cellular model [172].

Recently, Porta et al. clearly demonstrated that tumor-derived PGE2 leads to the nuclear accumulation of p50-NF- $\mathrm{kB}$ in M-MDSCs, resulting in a reduction of tumor necrosis factor (TNF) $\alpha$ expression and diverting their response to IFN $\gamma$. In agreement, the treatment with butaprost (PGE2 receptor antagonist) is able to reprogram M-MDSCs towards a "NOS2 ${ }^{\text {low }} / \mathrm{TNF} \alpha^{\text {high }}$ phenotype", thus, restoring the antitumor activity of IFN $\gamma$ [160]. An important role of MDSCs in the tumor is also to control cancer stem-like cells. It has been demonstrated both in vitro and in vivo that MDSCs induced by tumor-derived G-CSF enhance the stemness of cervical cancer cells by producing PGE2. Moreover, PGE2 produced by MDSC increases tumor PD-L1 expression in ovarian cancer cells, in an mTOR-dependent mechanism. Accordingly, the treatment with celecoxib inhibits the induction of cancer stem-like cells and enhances the efficacy of common chemotherapy (e.g. cisplatin). Importantly, the authors have translated these pieces of evidence for humans and they found a positive correlation between MDSCs, PGE2, and CSCs in clinical samples [173,174].

\subsubsection{PGE2, MDSCs, and Resistance to Immunotherapy}

Although immunotherapies have been found effective in several types of cancers (e.g., anti-PD-L1 and anti-PD-1 therapies), a portion of patients still fail to respond to therapy, and there is an urgent need to discover the mechanism at the basis of this resistance. In this setting, Prima et al. found that co-culture of BM cells with bladder tumor cells promotes strong expression of PD-L1 in M-MDSCs [161]. Tumor-infiltrating PD-L1 ${ }^{+}$cells isolated from tumor-bearing mice express high levels of PGE2 synthase 1 (mPGES1) and COX-2. Interestingly, the treatment with mPGES1/COX-2 inhibitors reduces the PD-L1 expression in MDSCs, suggesting that reprogramming PGE2 metabolism in a tumor microenvironment provides an opportunity to reduce immune suppression and may increase the efficacy of immunotherapy. Moreover, Hou et al. demonstrated that tumoral PGE2 is a key mediator of immunotherapy resistance (including virotherapy). Indeed, they have highlighted a decrease of Treg, but not of the number of MDSCs, after viral therapy, in different tumor models (e.g., 4T1, MC38), suggesting that MDSCs can block the immunotherapeutic activity of these vectors. The authors found a correlation between elevated levels of PGE2 and the suppressive profiles of tumors as well as with 
high levels of PMN-MDSCs, and using viral vectors engineered to target PGE2, they were able to alter the cancer immune status [175].

\subsection{PGE2 and Tumor-Associated Macrophages}

Macrophages display marked plasticity since they can polarize to M1- (pro-inflammatory) and M2-like (anti-inflammatory) phenotypes by various stimulations (e.g., IFN $\gamma$, LPS, IL-4) in inflamed tissues or in cancers. In a tumoral setting, it is well accepted that macrophages acquire the M2-like phenotype and become the so-called tumor-associated macrophages (TAMs). They could promote migration, metastatization, and angiogenesis and suppress regulatory immune circuits.

\subsubsection{Role of PGE2 in Controlling Macrophage Polarization}

The key role of PGE2 in the regulation of macrophage polarization has been extensively described. Indeed, it has been demonstrated that human peripheral blood mononuclear cells (PBMCs) cultured in the presence of GM-CSF and IL-4 normally differentiate into DCs, while the stimulation with PGE2 suppresses the formation of DCs and shifts the differentiation into the M2-like macrophages. The mechanism at the basis of this switch in the differentiation process seems to be dependent on the activation of EP4, since the treatment with E7046 (EP4 antagonist) is able to revert the differentiation to M2-like macrophages [176-179]. These data prove that PGE2 promotes M2 polarization, therefore, contributing to the enhancement of the anti-tumor immunity. In accordance, macrophages usually express EP2 and EP4, but not EP1 or EP3. The treatment with EP4 antagonist (E7046) of ApcMin/+ mice determines the change of TAM phenotype from M2 to M1 polarization, suggesting that EP4 is essential for PGE2-dependent M2 polarization [177]. Similarly, it has been proved in a glioblastoma model that PGE2, secreted by glioblastoma cancer stem cells, is able to convert macrophages into M2-TAMs [176]. Finally, as already reported in the MDSC section, the activation of COX-2/mPGES1/PGE2 pathways promotes PD-L1 expression by TAMs [180].

\subsubsection{Role of PGE2 in Controlling Macrophage Migration}

PGE2 controls also macrophage migration into the tumor. Indeed, it has been demonstrated that PGE2 leads to CCL2 up-regulation, a key chemokine involved in macrophage recruitment in the tumor. Moreover, in a mouse model of gastric cancer, the treatment with EP4 antagonist reduces the recruitment of M2-like macrophages and consequently the tumoral growth [179].

\subsection{PGE2 and Dendritic Cells}

Dendritic cells (DCs) are able to exert different activities including being sentinels of the immune system, checking continuously the immune niche. DCs are not effector cells against pathogens, but they control adaptive immunity, presenting the foreign antigens [181]. All DCs originate from a macrophage/dendritic cell progenitor (MDP) present in the bone marrow which further differentiates itself into the monocyte/macrophage lineage or to the common dendritic cell progenitor (CDP). CDP in the bone marrow differentiates in turn to both plasmacytoid $\mathrm{DC}(\mathrm{pDC})$ and pre-DC progenitors. pDCs go to the bloodstream as mature functional cells. Therefore, pre-DCs migrate through the vascular system to their final location in the tissues or lymph nodes, where they differentiate into conventional DCs (cDCs) [182,183]. Apart from antigen presentation, DCs deliver co-stimulatory signals and produce cytokines which are necessary for instructing appropriate effector or regulatory T-cell responses. Antigen-presenting cells, as dendritic cells, are able to guide immune response to tumor antigens. Circulating DC levels and activity are reduced in cancer patients as compared with healthy subjects, correlating with the severity of disease. 


\subsubsection{PGE2 and DC Differentiation}

Notably, a key role of PGE in controlling DC differentiation has been highlighted by different authors. Indeed, in tumor models of colon cancers, PGE2 promotes tumor growth by suppressing DC differentiation from bone marrow progenitors [79]. Furthermore, PGE2 inhibits the antigen presentation ability of BM-derived DCs by reduction of MHC II expression and upregulation of IL-10 through EP2 and EP4 [79]. PGE2 has also been shown to switch the function of DCs from induction of immunity to T-cell tolerance via upregulation of CD25 and indoleamine 2,3-dioxygenase (IDO1). Furthermore, PGE2 unbalances the IL-12/IL-23 axis using EP2 and EP4 receptors in favor of IL-23 which brings an increase of the number of Th17 cells in vitro [79].

Importantly, Ogawa et al. have reported that COX-2-derived PGE2 is essential for the formation of a premetastatic niche and lymph node metastasis (LNM). Using a murine model of Lewis lung carcinoma (LLC), they have shown COX-2 overexpression in CDCs. The administration of a COX-2 inhibitor, plus a stromal cell-derived factor 1 (SDF-1) antagonist and a CXCR4 neutralizing antibody, determine the reduction of LNM. Moreover, LNM is reduced in KO mice for EP3, suggesting that the effect of PGE2 on DCs could be mediated by the activation of EP3, despite other receptors. Indeed, compared with WT CD11 $\mathrm{c}^{+} \mathrm{DC}$, injection of EP3-deficient CD11 $\mathrm{c}^{+} \mathrm{DC}$ s dramatically reduces accumulation of SDF- $1^{+} \mathrm{CD} 11 \mathrm{c}^{+}$DCs in regional lymph nodes (LNs) and lymph nodes metastasis (LNM) in LLC-injected mice, showing a COX-2/EP3-dependent signaling [184].

\subsubsection{PGE2 and DC Migration}

Migration and storing of cDCs to lymphoid organs are essential for T-cell-induced response against tumors. However, tumor niche might let some tumor cells escape from the immune response by reducing DC migration. A key role of PGE2 in this setting has been proven. The medium of murine prostate cancer cells inhibits migration of BM-DCs and splenic CDCs through the activation of CC chemokine receptor-7 (CCR7) ligand CCL19 in vitro, and migration to draining lymph nodes in vivo [185]. However, the treatment with PGE2 rescues this impairment of DC migration with upregulation of CCR7 and inhibition of LXR $\alpha$. Moreover, in prostate-cancer-bearing mice, PGE2 treatment inhibits tumor growth and induces more tumor-infiltrating T cells and CD11c dendritic cells in tumor niche [185].

\subsection{PGE2 and Natural Killer Cells}

Natural killer (NK) cells are innate immune lymphocytes, with a role in the regulation of innate and adaptive immune response which primarily function to lyse tumor cells. NK cells targeting tumor-mediated mechanisms include granule exocytosis, death receptor-mediated killing, and interferon (IFN)- $\gamma$ release [186]. Activation receptors are NK group 2, member D (NKG2D) and natural cytotoxicity receptors NKp44, NKp46, and NKp30. NK cells produce perforin and granzyme $\mathrm{B}$ to penetrate into target cells and bring them to death. Activated NK cells also secrete IFN- $\gamma$ to stimulate other immune cell types and activate an immune response [186]. Various types of tumor cells express ligands that are recognized by NK cells and stimulate their cytotoxic activity. NKG2D binds major histocompatibility complex class I polypeptide-related sequence A/B expressed on the surface of cancer cells, proliferating cell nuclear antigen binds to NKp44, while B7-H6 molecule is recognized by NKp30. Usually, ligands are more expressed in tumor cells than in normal cells [187].

\section{PGE2 and NK Activity}

The general idea is that NK cells could reject human tumors, influencing clinical outcome. In 1992, Fulton et al. have firstly evaluated that PGE2 receptor, without distinguishing the isoform, is overexpressed in metastatic murine mammary tumor, and PGE2 itself is able to induce NK activity inhibition [188]. Of note, NK cells express EP2, EP3, and EP4, but not EP1 [189]. Several manuscripts, and several years later, it has been highlighted the efficacy of NK to target cancer cells, whose activity is punctually suppressed by PGE2 production, usually secreted by tumoral cells. Suppressed NK cell 
activity has been found in human colorectal cancer and it is an important prognostic factor for the development of metastases [79]. Similarly, tumor-infiltrating NK cell levels are associated with an improved rate of survival in gastric cancer, negatively correlating with COX-2 levels, and enhancing lung metastases in rats [79]. Moreover, modulation of EP4 receptor signaling mediates the effects of PGE2 on the promotion of breast cancer metastasis and suppression of NK cell function in a murine model of metastatic breast cancer, suggesting that EP4 may be crucial for the activation of NK by PGE2. In this case, PGE2 suppresses NK cell function via multiple mechanisms: (i) downregulating NK receptors via a cAMP/PKA pathway, (ii) inhibiting production of IFN- $\gamma$ by NK cells and IL-12-induced or IL-18-induced IFN- $\gamma$ expression in NK cells via EP2 receptor, and (iii) inhibiting NK cell proliferation and inducing apoptosis [79]. PGE2 inhibits the killing of target cells by NK cells activated through NCR, CD16, or NKG2D. Moreover, the percentage of CD107a ${ }^{+}$NK cells is significantly inhibited by increasing doses of PGE2 in a dose-dependent manner [189]. Both melanoma and hepatocellular carcinoma cells are able to inhibit the expression of NK receptors that trigger their immune function, including NKp30, NKp44, and NKG2D, with the impairment of NK-cell-mediated cytolytic activity against melanoma cells, through IDO1 and PGE2 expression [190,191]. Moreover, Park et al. have also highlighted that thyroid cancer cells suppress the cytolytic activity of NK cells through PGE2 secretion, downregulating NKp44 and NKp30 receptors. They have described that PGE2 and COX-2 are over-expressed in anaplastic thyroid cancer cells [192] and that also cancer-associated fibroblasts (CAFs) are responsible for PGE2 production [193]. Several NK functions, such as lysis, migration, and cytokine production, are compromised in tumor-bearing (injected with 66.1 cells) mice, producing PGE2. Indeed, PGE2 interferes with the potential of NK cells to migrate, exerting cytotoxic activity, and secreting IFN $\gamma$, with a mechanism dependent on the activation of EP2 and EP4 receptors. Importantly, NK cells are susceptible to inhibition after the treatment with EP4 and EP2 agonists compared to NK cells from healthy mice. Holt et al. have reported that an EP4 antagonist (frondoside A) inhibits breast tumor metastasis in an NK-dependent manner and protects IFN $\gamma$ production by NK cells from PGE2 mediated suppression [194,195]. Similarly, the EP4 antagonist AH23848 reduces the ability of tumor cells to colonize the lungs or to spontaneously metastasize from the mammary gland. Of note, metastasis inhibition is lost in mice lacking either functional NK cells or interferon- $\gamma$ [196]. Lastly, unique molecule EP4 antagonist (RQ-15986) is able to reduce tumoral mass in a syngeneic murine model of metastatic breast cancer. NK-cell functions are markedly depressed in mice bearing murine mammary tumor 66.1 or 410.4 cells due to the actions of PGE2 on NK cell EP4 receptors [197]. Taken together, all these reports clearly demonstrate that the activation of the EP4 receptor is essential for the PGE2 activation of NK cells.

Another emerging role of NKs is that they are able to crosstalk with both T cells and dendritic cells. The cytokine- and chemokine-producing capacity, T-cell polarization, migration, and stimulatory functions of DCs are finely regulated by activated NK cells. NK functions require close interactions with activated DCs. Cell-membrane-associated molecules and soluble mediators, including cytokines and prostaglandins, contribute to the bidirectional crosstalk between DCs and NK cells, usually inhibited by PGE2 [198].

\subsection{PGE2 and T-Cells}

HSCs differentiate into multipotent progenitors (MPPs) which could be differentiated in both myeloid and lymphoid cells. MPPs differentiate to a common lymphoid progenitor (CLP) which converts exclusively into T, B, or NK cells. CLPs migrate to the thymus, where they implant themselves. First, cells that implant in the thymus are the double-negative ones, as they express neither the CD4 nor the CD8 co-receptor, while double positive CD4/CD8 migrate into the cortex of the thymus and present self-antigens. If they interact with MHC-I or MHC-II, they survive; if they do not, they will be discarded. If the double-positive cells interact with MHC class II, molecules will differentiate in $\mathrm{CD} 4^{+}$ cells-CD8 ${ }^{+}$cells if they interact with MHC class I [199]. Differentiated T cells have an important role in adaptive immunity and are subdivided into (i) $\mathrm{CD}^{+} \mathrm{T}$ cells that have cytotoxic activity, able to 
kill infected or tumor cells; (ii) $\mathrm{CD} 4^{+} \mathrm{T}$ cells, or "helper cells", that release cytokines and activate indirectly regulatory B cells; and (iii) regulatory $\mathrm{T}$ cells (Treg) usually activated by tumor cells to prevent their killing.

Several studies have underlined the effect of PGE2 on T cells. For example, it has been reported that PGE2 is able to inhibit the proliferation of T cells in a dose-dependent manner in vitro. A comparison between IFN- $\gamma$ and IL-4 production showed that PGE2 increases the relative ratio of IL- 4 to IFN- $\gamma$ in $\mathrm{CD}^{+} \mathrm{T}$ cell culture and regulates $\mathrm{CD} 4^{+} \mathrm{T}$ cells toward $\mathrm{Th} 2$ development. This mechanism seems to be primarily dependent on IDO-overexpression, determining Tregs formation and development [200]. In support of these findings, it has been reported that murine renal carcinoma (Renca) cells over-secrete PGE2 and consequently inhibit antitumor cytotoxic T lymphocyte (CTL) responses in vivo by preventing the IFN $\gamma$-dependent upregulation of ICAM-1 responsible for the initial priming of naïve $\mathrm{CD}^{+} \mathrm{T}$ cells. In addition, exogenous IFN $\gamma$ abolishes PGE2-mediated suppression on naïve CD8 T-cell priming, and overexpression of ICAM-1 by tumor cells re-establishes IFN $\gamma$ production [201]. PGE2 immunosuppression may be an indirect consequence determined by COX-2 overexpression, as in melanoma. In a number of tumor cell lines, constitutive IDO1 expression depends on COX-2 and PGE2 which upon autocrine signaling through the EP receptor activates IDO1 via the PKC and PI3K pathways. Moreover, most of these tumors have been associated with PI3K or MAPK mutations which may support constitutive IDO1 expression, and usually lack T-cell infiltration and fail to immunotherapy [202].

$\mathrm{CD}^{+} \mathrm{CD} 25^{+} \mathrm{T}$ reg cells play an important role in the maintenance of immunologic self-tolerance in non-small cell lung cancer. $\mathrm{CD} 4^{+} \mathrm{CD} 25^{+} \mathrm{T}$ reg cell activities increase in lung cancer and appear to play an important role in suppressing antitumor immune responses. COX-2/PGE2 signaling induces expression of Foxp3 and increases Treg properties. PGE2-mediated induction of Treg cell Foxp3 gene expression is significantly down-expressed in the absence of the EP4 receptor and totally eliminated in the absence of the EP2 receptor. In vivo, COX-2 inhibition reduces Treg cell frequency and activity, attenuates Foxp3 expression in tumor-infiltrating lymphocytes (TILs), and decreases tumor weight. Adoptive Treg cells transfer or administration of PGE2 to mice treated with COX-2 inhibitor are able to overturn these effects [203]. Another important piece of evidence is reported by Kim et al. who have emphasized GM-CSF potential in cancer vaccines through IL9-producing Th (Th9) cells. GM-CSF improves Th9 cell differentiation by regulating the COX-2-PGE2 pathway and it is able to inhibit the differentiation of induced regulatory $\mathrm{T}$ cells in vitro and in vivo. GM-CSF-activated monocyte-derived dendritic cells convert tumor-specific naïve Th cells into Th9 cells and delay tumor growth by inducing antitumor CTLs in an IL9-dependent manner [204].

Moreover, fibroblastic reticular cells (FRCs) in the T-cell zone of lymph nodes are essential for T-cell survival, mobility, and tolerance. FRCs are able to limit T-cell activation, secreting PGE2 due to COX-2 overexpression in immune cells [205]. Another important role of PGE2, mainly related to immunotherapy resistance, is its ability to promote the expression of PD-1 and TIM-3 in T-cells increasing the interaction with PD-L1 and PD-L2, highly expressed on CAFs. Blocking the activity of PGE2 partially restores the proliferative capacity of both $\mathrm{CD}^{+}$and $\mathrm{CD} 8^{+} \mathrm{T}$-cells [206].

All these reports demonstrate an important function of PGE2 in controlling the balance between Th1, Th2, and Treg, with a key role in the induction of Treg and Th2 phenotype resulting in a promotion of immunosuppressive niche and tumor growth.

\section{Conclusions}

The importance of inflammation in driving the predisposition to cancer has been widely documented. Starting from this observation, in recent years the scientific community has begun to repurpose anti-inflammatory agents not only for the prevention but also as a therapeutic option in cancer. Among the inflammatory mediators, PGE2 is known to play a pivotal role in regulating the inflammatory milieu that drives cancer onset and progression. Several studies have demonstrated that PGE2 is able to activate growth factor signaling; promote cancer cell growth and resistance to apoptosis 
and metastasis; and to modulate immune response. Extensive clinical and epidemiological studies support the idea that PGE2 level reduction could be useful to prevent tumor initiation, to reprogram anti-tumor immunity, to inhibit tumor growth and metastasis, and, finally, to increase the efficacy of current pharmacological and immunological therapies.

To date, the anti-tumoral potential of aspirin and coxibs has been well studied in preclinical and clinical settings. Notably, several clinical trials aimed to study the efficacy of coxibs alone or in combination are under investigation. For example, the clinical efficacy of celecoxib alone is under phase I and II clinical trials for treating patients with stage I, stage II, or stage IIIA non-small cell lung cancer and advanced carcinoma of the cervix (NCT00030407 and NCT00023660 clinicaltrials.gov). Further, the combination of celecoxib with irinotecan, cisplatin, and radiation therapy is under investigation in esophageal cancer (NCT00023660 clinicaltrials.gov).

Of note, the current therapies targeting PGE2 using NSAIDs or COX-2 inhibitors have sometimes failed due to the global prostanoid suppression which in turn results in severe side effects [207]. It is, therefore, more plausible and clinically relevant to act not on PGE2 biosynthesis, but mainly on the antagonism of EP receptors. For this reason, numerous small-molecule ligands targeting EP receptors have been developed and are under investigation both as conventional anticancer agents and as immunomodulating drugs (e.g., ONO-8711 for EP1; PF-04418948 for EP2; ONO-AE3-240 for EP3; $\mathrm{AH} 23848 \mathrm{~b}$ for EP4). For example, the antagonist of EP4, RQ-00000007, is under clinical evaluation in combination with gemcitabine for prostate cancer, non-small cell lung cancer, and breast cancer (NCT02538432 www.clinicaltrials.gov). The TPST-1495 dual EP2 and EP4 antagonist is in phase 1a/1b as single treatment or in association with pembrolizumab in solid tumors (bladder cancer, triple negative breast cancer, gastric cancer) (NCT04344795 clinicaltrials.gov).

This review has highlighted the pleiotropic role of PGE2 in controlling tumor cells but also the tumor microenvironment (TME), suggesting that targeting PGE2 could be a good strategy to both act on cancer cells but also on immune cells. Accordingly, the putative immunomodulatory effect of blocking the PGE2 pathway is under investigation. For example, a phase I clinical study has already been started with E7046, an EP4 inhibitor, with a potent immunosuppressive effect on myeloid cells in the TME (NCT02540291: https://clinicaltrials.gov/ct2/show/study/NCT02540291).

In conclusion, PGE2 represents an old target with pleiotropic functions in TME with a new potential clinical impact. The usage of NSAIDS and COX-2-inhibitors as anti-cancer agents may be bypassed by selective EP antagonists which may overcome severe side effects and, therefore, increase the real potential of targeting the PGE2 pathway as a novel therapeutic approach in the clinical setting.

Author Contributions: Conceptualization, F.F., C.T., and L.T.; writing—original draft preparation, F.F., C.T., J.E., G.C., and E.B.; writing - review and editing, F.F., C.T., and L.T.; supervision, L.T. All authors have read and agreed to the published version of the manuscript.

Funding: MIUR (Progetto Dipartimento di Eccellenza 2018-2022) to L.T., F.F., and J.E., Fondi FRG 2019 (Università degli Studi di Pavia) to C.T.; Fondazione Umberto Veronesi to C.T.

Acknowledgments: The authors thank Servier Medical Art (SMART) for the preparation of Figures 1 and 2, and BioRender for the preparation of Figure 3.

Conflicts of Interest: The authors declare no conflict of interest

\section{References}

1. De Martel, C.; Ferlay, J.; Franceschi, S.; Vignat, J.; Bray, F.; Forman, D.; Plummer, M. Global burden of cancers attributable to infections in 2008: A review and synthetic analysis. Lancet Oncol. 2012, 13, 607-615. [CrossRef]

2. Schottenfeld, D.; Beebe-Dimmer, J. The cancer burden attributable to biologic agents. Ann. Epidemiol. 2015, 25, 183-187. [CrossRef] [PubMed]

3. Rothwell, P.M.; Fowkes, F.G.R.; Belch, J.F.; Ogawa, H.; Warlow, C.P.; Meade, T.W. Effect of daily aspirin on long-term risk of death due to cancer: Analysis of individual patient data from randomised trials. Lancet 2011, 377, 31-41. [CrossRef] 
4. Cho, M.H.; Yoo, T.G.; Jeong, S.-M.; Shin, D.W. Association of aspirin, metformin, and statin use with gastric cancer incidence and mortality: A nationwide cohort study. Cancer Prev. Res. 2020. [CrossRef]

5. Lin, Y.S.; Yeh, C.C.; Huang, S.F.; Chou, Y.S.; Kuo, L.T.; Sung, F.C.; Muo, C.H.; Su, C.T.; Su, F.H. Aspirin associated with risk reduction of secondary primary cancer for patients with head and neck cancer: A population-based analysis. PLoS ONE 2018, 13, e0199014. [CrossRef]

6. Ma, Y.; Brusselaers, N. Maintenance use of aspirin or other non-steroidal anti-inflammatory drugs (NSAIDs) and prostate cancer risk. Prostate Cancer Prostatic Dis. 2018, 21, 147-152. [CrossRef]

7. Veettil, S.K.; Lim, K.G.; Ching, S.M.; Saokaew, S.; Phisalprapa, P.; Chaiyakunapruk, N. Effects of aspirin and non-aspirin nonsteroidal anti-inflammatory drugs on the incidence of recurrent colorectal adenomas: A systematic review with meta-analysis and trial sequential analysis of randomized clinical trials. BMC Cancer 2017, 17, 763. [CrossRef]

8. Donnini, S.; Finetti, F.; Terzuoli, E.; Bazzani, L.; Ziche, M. Targeting PGE2 signaling in tumor progression and angiogenesis. For. Immunopathol. Dis. Therap. 2014. [CrossRef]

9. Dubois, R.N.; Abramson, S.B.; Crofford, L.; Gupta, R.A.; Simon, L.S.; van de Putte, L.B.A.; Lipsky, P.E. Cyclooxygenase in Biology and Disease. FASEB J. 1998, 12, 1063-1073. [CrossRef]

10. Simmons, D.L.; Botting, R.M.; Hla, T. Cyclooxygenase Isozymes: The Biology of Prostaglandin Synthesis and Inhibition. Pharmacol. Rev. 2004, 56, 387-437. [CrossRef]

11. Wang, D.; Dubois, R.N. Eicosanoids and cancer. Nat. Rev. Cancer 2010, 10, 181-193. [CrossRef] [PubMed]

12. Murakami, M.; Nakatani, Y.; Tanioka, T.; Kudo, I.; Synthase, P.E. Molecular Biology of the Arachidonate Cascade. Prostaglandins Other Lipid Mediat. 2002, 68-69, 383-399. [CrossRef]

13. Samuelsson, B.; Morgenstern, R.; Jakobsson, J. Membrane Prostaglandin E Synthase-1: A Novel Therapeutic Target. Pharmacol. Rev. 2007, 59, 207-224. [CrossRef] [PubMed]

14. Tai, H.H. Prostaglandin catabolic enzymes as tumor suppressors. Cancer Metastasis Rev. 2011, 30, 409-417. [CrossRef] [PubMed]

15. O'Callaghan, G.; Houston, A. Prostaglandin E2 and the EP receptors in malignancy: Possible therapeutic targets? Br. J. Pharmacol. 2015, 172, 5239-5250. [CrossRef] [PubMed]

16. Cai, Y.; Yousef, A.; Grandis, J.R.; Johnson, D.E. NSAID therapy for PIK3CA-Altered colorectal, breast, and head and neck cancer. Adv. Biol. Regul. 2020, 75, 100653. [CrossRef]

17. Harris, R.E.; Beebe-Donk, J.; Doss, H.; Doss, D.B. Aspirin, ibuprofen, and other non-steroidal anti-inflammatory drugs in cancer prevention: A critical review of non-selective COX-2 blockade (review). Oncol. Rep. 2005, 13, 559-583. [CrossRef]

18. Drew, D.A.; Schuck, M.M.; Magicheva-Gupta, M.V.; Stewart, K.O.; Gilpin, K.K.; Miller, P.; Parziale, M.P.; Pond, E.N.; Takacsi-Nagy, O.; Zerjav, D.C.; et al. Effect of Low-dose and Standard-dose Aspirin on PGE 2 Biosynthesis Among Individuals with Colorectal Adenomas: A Randomized Clinical Trial. Cancer Prev. Res. 2020. [CrossRef]

19. Fang, H.Y.; Lin, T.S.; Lin, J.P.; Wu, Y.C.; Chow, K.C.; Wang, L.S. Cyclooxygenase-2 in human non-small cell lung cancer. Eur. J. Surg. Oncol. 2003, 29, 171-177. [CrossRef]

20. Yoshimatsu, K.; Subbaramaiah, K.; Dannenberg, A.J.; DeLellis, R.A.; Golijanin, D.; Paty, P.B.; Soslow, R.A.; Jakobsson, P.J. Inducible microsomal prostaglandin E synthase is overexpressed in colorectal adenomas and cancer. Clin. Cancer Res. 2001, 7, 3971-3976.

21. Sano, H.; Kawahito, Y.; Wilder, R.L.; Hashiramoto, A.; Mukai, S.; Asai, K.; Kimura, S.; Kato, H.; Kondo, M.; Hla, T. Expression of Cyclooxygenase-1and -2 in Human Colorectal Cancer1. Cancer Res. 1995, 55, 3785-3790. [PubMed]

22. Roelofs, H.M.J.; Morsche, R.H.M.t.; van Heumen, B.W.H.; Nagengast, F.M.; Peters, W.H.M. Over-expression of COX-2 mRNA in colorectal cancer. BMC Gastroenterol. 2014, 14, 3-8. [CrossRef] [PubMed]

23. Half, E.; Tang, X.M.; Gwyn, K.; Sahin, A.; Wathen, K.; Sinicrope, F.A. Cyclooxygenase-2 expression in human breast cancers and adjacent ductal carcinoma in situ. Cancer Res. 2002, 62, 1676-1681. [PubMed]

24. Mehrotra, S.; Morimiya, A.; Agarwal, B.; Konger, R.; Badve, S. Microsomal prostaglandin E2 synthase-1 in breast cancer: A potential target for therapy. J. Pathol. 2006, 208, 356-363. [CrossRef]

25. Khor, L.Y.; Bae, K.; Pollack, A.; Hammond, M.E.H.; Grignon, D.J.; Venkatesan, V.M.; Rosenthal, S.A.; Ritter, M.A.; Sandler, H.M.; Hanks, G.E.; et al. COX-2 expression predicts prostate-cancer outcome: Analysis of data from the RTOG 92-02 trial. Lancet Oncol. 2007, 8, 912-920. [CrossRef] 
26. Finetti, F.; Terzuoli, E.; Giachetti, A.; Santi, R.; Villari, D.; Hanaka, H.; Radmark, O.; Ziche, M.; Donnini, S. MPGES-1 in prostate cancer controls stemness and amplifies epidermal growth factor receptor-driven oncogenicity. Endocr. Relat. Cancer 2015, 22. [CrossRef]

27. Panza, E.; de Cicco, P.; Ercolano, G.; Armogida, C.; Scognamiglio, G.; Anniciello, A.M.; Botti, G.; Cirino, G.; Ianaro, A. Differential expression of cyclooxygenase-2 in metastatic melanoma affects progression free survival. Oncotarget 2016, 7, 57077-57085. [CrossRef]

28. Koga, H.; Sakisaka, S.; Ohishi, M.; Kawaguchi, T.; Taniguchi, E.; Sasatomi, K.; Harada, M.; Kusaba, T.; Tanaka, M.; Kimura, R.; et al. Expression of cyclooxygenase-2 in human hepatocellular carcinoma: Relevance to tumor dedifferentiation. Hepatology 1999, 29, 688-696. [CrossRef]

29. Zang, S.; Ni, M.; Lian, Y.; Zhang, Y.; Liu, J.; Huang, A. Expression of microsomal prostaglandin E2 synthase-1 and its role in human hepatocellular carcinoma. Hum. Pathol. 2013, 44, 1681-1687. [CrossRef]

30. Zarghi, A.; Arfaei, S. Selective COX-2 Inhibitors: A Review of Their Structure-Activity Relationships. Iran. J. Pharm. Res. 2011, 10, 655-683.

31. Harris, R. Beebe, Alshafie, Reduction in cancer risk by selective and nonselective cyclooxygenase-2 (COX-2) inhibitors. J. Exp. Pharmacol. 2012, 91. [CrossRef]

32. Liao, X.; Lochhead, P.; Nishihara, R.; Morikawa, T.; Kuchiba, A.; Yamauchi, M.; Imamura, Y.; Qian, Z.R.; Baba, Y.; Shima, K.; et al. Aspirin Use, Tumor PIK3CA Mutation, and Colorectal-Cancer Survival. N. Engl. J. Med. 2012, 367, 1596-1606. [CrossRef] [PubMed]

33. Paleari, L.; Puntoni, M.; Clavarezza, M.; DeCensi, M.; Cuzick, J.; DeCensi, A. PIK3CA Mutation, Aspirin Use after Diagnosis and Survival of Colorectal Cancer. A Systematic Review and Meta-analysis of Epidemiological Studies. Clin. Oncol. 2016, 28, 317-326. [CrossRef] [PubMed]

34. Patrignani, P.; Patrono, C. Aspirin and Cancer. J. Am. Coll. Cardiol. 2016, 68, 967-976. [CrossRef] [PubMed]

35. Patrono, C.; Rocca, B. Aspirin: Promise and resistance in the new millennium. Arterioscler. Thromb. Vasc. Biol. 2008, 28, 25-32. [CrossRef]

36. Soriano, L.C.; Soriano-Gabarró, M.; Rodríguez, L.A.G. Trends in the contemporary incidence of colorectal cancer and patient characteristics in the United Kingdom: A population-based cohort study using The Health Improvement Network. BMC Cancer 2018, 18, 402. [CrossRef]

37. Thun, M.J.; Jacobs, E.J.; Patrono, C. The role of aspirin in cancer prevention. Nat. Rev. Clin. Oncol. 2012, 9, 259-267. [CrossRef]

38. Algra, A.M.; Rothwell, P.M. Effects of regular aspirin on long-term cancer incidence and metastasis: A systematic comparison of evidence from observational studies versus randomised trials. Lancet Oncol. 2012, 13, 518-527. [CrossRef]

39. Andreotti, F.; de Caterina, R.; Crea, F. Aspirin and the prevention of a common disease: Colorectal cancer. Int. J. Cardiol. 2017, 248, 394-395. [CrossRef]

40. Cole, B.F.; Logan, R.F.; Halabi, S.; Benamouzig, R.; Sandler, R.S.; Grainge, M.J.; Chaussade, S.; Baron, J.A. Aspirin for the chemoprevention of colorectal adenomas: Meta-analysis of the randomized trials. J. Natl. Cancer Inst. 2009, 101, 256-266. [CrossRef]

41. Elwood, P.C.; Morgan, G.; Pickering, J.E.; Galante, J.; Weightman, A.L.; Morris, D.; Kelson, M.; Dolwani, S. Aspirin in the treatment of cancer: Reductions in metastatic spread and in mortality: A systematic review and meta-analyses of published studies. PLOS ONE 2016, 11, e0152402. [CrossRef] [PubMed]

42. Giovannucci, E. Aspirin Reduces the Risk of Colorectal Cancer in Women. Nurse Pract. 1995, $20,90$. [CrossRef]

43. Jonsson, F.; Yin, L.; Lundholm, C.; Smedby, K.E.; Czene, K.; Pawitan, Y. Low-dose aspirin use and cancer characteristics: A population-based cohort study. Br. J. Cancer 2013, 109, 1921-1925. [CrossRef] [PubMed]

44. Joharatnam-Hogan, N.; Cafferty, F.; Hubner, R.; Swinson, D.; Sothi, S.; Gupta, K.; Falk, S.; Patel, K.; Warner, N.; Kunene, V.; et al. Aspirin as an adjuvant treatment for cancer: Feasibility results from the Add-Aspirin randomised trial. Lancet Gastroenterol. Hepatol. 2019, 4, 854-862. [CrossRef]

45. Kune, G.A.; Kune, S.; Watson, L.F. Colorectal cancer risk, chronic illnesses, operations and medications: Case-control results from the Melbourne colorectal cancer study. Int. J. Epidemiol. 2007, 36, 951-957. [CrossRef] [PubMed]

46. Chen, W.Y.; Holmes, M.D. Role of Aspirin in Breast Cancer Survival. Curr. Oncol. Rep. 2017, 19. [CrossRef]

47. Fraser, D.M.; Sullivan, F.M.; Thompson, A.M.; McCowan, C. Aspirin use and survival after the diagnosis of breast cancer: A population-based cohort study. Br. J. Cancer 2014, 111, 623-627. [CrossRef] 
48. Holmes, M.D.; Olsson, H.; Pawitan, Y.; Holm, J.; Lundholm, C.; Andersson, T.M.L.; Adami, H.O.; Askling, J.; Smedby, K.E. Aspirin intake and breast cancer survival-a nation-wide study using prospectively recorded data in Sweden. BMC Cancer 2014, 14, 391. [CrossRef]

49. Huang, X.Z.; Gao, P.; Sun, J.X.; Song, Y.X.; Tsai, C.C.; Liu, J.; Chen, X.W.; Chen, P.; Xu, H.M.; Wang, Z.N. Aspirin and nonsteroidal anti-inflammatory drugs after but not before diagnosis are associated with improved breast cancer survival: A meta-analysis. Cancer Causes Control. 2015, 26, 589-600. [CrossRef]

50. Zhong, S.; Zhang, X.; Chen, L.; Ma, T.; Tang, J.; Zhao, J. Association between aspirin use and mortality in breast cancer patients: A meta-analysis of observational studies. Breast Cancer Res. Treat. 2015, 150, $199-207$. [CrossRef]

51. Zhao, Y.S.; Zhu, S.; Li, X.W.; Wang, F.; Hu, F.L.; Li, D.D.; Zhang, W.C.; Li, X. Association between NSAIDs use and breast cancer risk: A systematic review and meta-analysis. Breast Cancer Res. Treat. 2009, 117, 141-150. [CrossRef] [PubMed]

52. Ahmadi, N.; Goldman, R.; Seillier-Moiseiwitsch, F.; Noone, A.-M.; Kosti, O.; Davidson, B.J. Decreased Risk of Squamous Cell Carcinoma of the Head and Neck in Users of Nonsteroidal Anti-Inflammatory Drugs. Int. J. Otolaryngol. 2010, 2010, 424161. [CrossRef] [PubMed]

53. Bosetti, C.; Talamini, R.; Franceschi, S.; Negri, E.; Garavello, W.; la Vecchia, C. Aspirin use and cancers of the upper aerodigestive tract. Br. J. Cancer 2003, 88, 672-674. [CrossRef] [PubMed]

54. Hedberg, M.L.; Peyser, N.D.; Bauman, J.E.; Gooding, W.E.; Li, H.; Bhola, N.E.; Zhu, T.R.; Zeng, Y.; Brand, T.M.; Kim, M.O.; et al. Use of nonsteroidal anti-inflammatory drugs predicts improved patient survival for PIK3CA-altered head and neck cancer. J. Exp. Med. 2019, 216, 419-427. [CrossRef] [PubMed]

55. Lumley, C.J.; Kaffenberger, T.M.; Desale, S.; Tefera, E.; Han, C.J.; Rafei, H.; Maxwell, J.H. Post-diagnosis aspirin use and survival in veterans with head and neck cancer. Head Neck. 2019, 41, 1220-1226. [CrossRef]

56. Macfarlane, T.V.; Macfarlane, G.J.; Thakker, N.S.; Benhamou, S.; Bouchardy, C.; Ahrens, W.; Pohlabeln, H.; Lagiou, P.; Lagiou, A.; Castellsague, X.; et al. Role of medical history and medication use in the aetiology of upper aerodigestive tract cancers in Europe: The ARCAGE study. Ann. Oncol. 2012, 23, 1053-1060. [CrossRef]

57. Macfarlane, T.V.; Lefevre, K.; Watson, M.C. Aspirin and non-steroidal anti-inflammatory drug use and the risk of upper aerodigestive tract cancer. Br. J. Cancer 2014, 111, 1852-1859. [CrossRef]

58. Macfarlane, T.V.; Murchie, P.; Watson, M.C. Aspirin and other non-steroidal anti-inflammatory drug prescriptions and survival after the diagnosis of head and neck and oesophageal cancer. Cancer Epidemiol. 2015, 39, 1015-1022. [CrossRef]

59. Panje, W.R. Regression of Head and Neck Carcinoma With a Prostaglandin-Synthesis Inhibitor. Arch. Otolaryngol. 1981, 107, 658-663. [CrossRef]

60. Wilson, J.C.; Anderson, L.A.; Murray, L.J.; Hughes, C.M. Non-steroidal anti-inflammatory drug and aspirin use and the risk of head and neck cancer: A systematic review. Cancer Causes Control. 2011, 22, $803-810$. [CrossRef]

61. Hochmuth, F.; Jochem, M.; Schlattmann, P. Meta-analysis of aspirin use and risk of lung cancer shows notable results. Eur. J. Cancer Prev. 2016, 25, 259-268. [CrossRef] [PubMed]

62. Shebl, F.M.; Sakoda, L.C.; Black, A.; Koshiol, J.; Andriole, G.L.; Grubb, R.; Church, T.R.; Chia, D.; Zhou, C.; $\mathrm{Chu}, \mathrm{L} . \mathrm{W}$; ; et al. Aspirin but not ibuprofen use is associated with reduced risk of prostate cancer: A PLCO Study. Br. J. Cancer 2012, 107, 207-214. [CrossRef]

63. Cuzick, J.; Otto, F.; Baron, J.A.; Brown, P.H.; Burn, J.; Greenwald, P.; Jankowski, J.; la Vecchia, C.; Meyskens, F.; Senn, H.J.; et al. Aspirin and non-steroidal anti-inflammatory drugs for cancer prevention: An international consensus statement. Lancet Oncol. 2009, 10, 501-507. [CrossRef]

64. Bosetti, C.; Gallus, S.; la Vecchia, C. Aspirin and cancer risk: An updated quantitative review to 2005. Cancer Causes Control. 2006, 17, 871-888. [CrossRef] [PubMed]

65. Prizment, A.E.; Folsom, A.R.; Anderson, K.E. Nonsteroidal anti-inflammatory drugs and risk for ovarian and endometrial cancers in the Iowa women's health study, Cancer Epidemiol. Biomarkers Prev. 2010, 19, 435-442. [CrossRef]

66. Kim, M.H.; Chang, J.; Kim, W.J.; Banerjee, S.; Park, S.M. Cumulative Dose Threshold for the Chemopreventive Effect of Aspirin Against Gastric Cancer. Am. J. Gastroenterol. 2018, 113, 845-854. [CrossRef]

67. Niikura, R.; Hirata, Y.; Hayakawa, Y.; Kawahara, T.; Yamada, A.; Koike, K. Effect of aspirin use on gastric cancer incidence and survival: A systematic review and meta-analysis. JGH Open 2020, 4, 117-125. [CrossRef] 
68. Venerito, M.; Vasapolli, R.; Rokkas, T.; Malfertheiner, P. Gastric cancer: Epidemiology, prevention, and therapy. Helicobacter 2018, 23, 2-7. [CrossRef]

69. Yang, P.; Zhou, Y.; Chen, B.; Wan, H.W.; Jia, G.Q.; Bai, H.L.; Wu, X.T. Aspirin use and the risk of gastric cancer: A meta-analysis. Dig. Dis. Sci. 2010, 55, 1533-1539. [CrossRef]

70. Wang, X.; Luo, Y.; Chen, T.; Zhang, K. Low-dose aspirin use and cancer-specific mortality: A meta-analysis of cohort studies. J. Public Health (Bangkok) 2019, fdz114. [CrossRef]

71. Falandry, C.; Debled, M.; Bachelot, T.; Delozier, T.; Crétin, J.; Romestaing, P.; Mille, D.; You, B.; Mauriac, L.; Pujade-Lauraine, E.; et al. Celecoxib and exemestane versus placebo and exemestane in postmenopausal metastatic breast cancer patients: A double-blind phase III GINECO study. Breast Cancer Res. Treat. 2009, 116, 501-508. [CrossRef] [PubMed]

72. Li, J.; Hao, Q.; Cao, W.; Vadgama, J.V.; Wu, Y. Celecoxib in breast cancer prevention and therapy. Cancer Manag. Res. 2018, 10, 4653-4667. [CrossRef] [PubMed]

73. Chow, L.W.C.; Yip, A.Y.S.; Loo, W.T.Y.; Lam, C.K.; Toi, M. Celecoxib anti-aromatase neoadjuvant (CAAN) trial for locally advanced breast cancer. J. Steroid Biochem. Mol. Biol. 2008, 111, 13-17. [CrossRef] [PubMed]

74. Martin, L.A.; Davies, G.L.S.; Weigel, M.T.; Betambeau, N.; Hills, M.J.; Salter, J.; Walsh, G.; A'Hern, R.; Dowsett, M. Pre-surgical study of the biological effects of the selective cyclo-oxygenase-2 inhibitor celecoxib in patients with primary breast cancer. Breast Cancer Res. Treat. 2010, 123, 829-836. [CrossRef]

75. Arun, B.; Goss, P. The role of COX-2 inhibition in breast cancer treatment and prevention. Semin. Oncol. 2004, 31, 22-29. [CrossRef]

76. Tołoczko-Iwaniuk, N.; Dziemiańczyk-Pakieła, D.; Nowaszewska, B.K.; Celińska-Janowicz, K.; Miltyk, W. Celecoxib in Cancer Therapy and Prevention-Review. Curr. Drug Targets 2018. [CrossRef]

77. Arber, N.; Eagle, C.J.; Spicak, J.; Rácz, I.; Dite, P.; Hajer, J.; Zavoral, M.; Lechuga, M.J.; Gerletti, P.; Tang, J.; et al. Celecoxib for the Prevention of Colorectal Adenomatous Polyps. N. Engl. J. Med. 2006, 355, 885-895. [CrossRef]

78. Baron, J.A.; Sandler, R.S.; Bresalier, R.S.; Quan, H.; Riddell, R.; Lanas, A.; Bolognese, J.A.; Oxenius, B.; Horgan, K.; Loftus, S.; et al. A Randomized Trial of Rofecoxib for the Chemoprevention of Colorectal Adenomas. Gastroenterology 2006, 131, 1674-1682. [CrossRef]

79. Wang, D.; Dubois, R.N. Role of prostanoids in gastrointestinal cancer. J. Clin. Investig. 2018, 128, $2732-2742$. [CrossRef]

80. Liu, R.; Xu, K.P.; Tan, G.S. Cyclooxygenase-2 inhibitors in lung cancer treatment: Bench to bed. Eur. J. Pharmacol. 2015, 769, 127-133. [CrossRef]

81. Mao, J.T.; Roth, M.D.; Fishbein, M.C.; Aberle, D.R.; Zhang, Z.F.; Rao, J.Y.; Tashkin, D.P.; Goodglick, L.; Holmes, E.C.; Cameron, R.B.; et al. Lung cancer chemoprevention with celecoxib in former smokers. Cancer Prev. Res. 2011, 4, 984-993. [CrossRef] [PubMed]

82. Csiki, I.; Morrow, J.D.; Sandler, A.; Shyr, Y.; Oates, J.; Williams, M.K.; Dang, T.; Carbone, D.P.; Johnson, D.H. Targeting cyclooxygenase-2 in recurrent non-small cell lung cancer: A phase II trial of celecoxib and docetaxel. Clin. Cancer Res. 2005, 11, 6634-6640. [CrossRef] [PubMed]

83. EKim, S.; Hong, W.K.; Lee, J.J.; Mao, L.; Morice, R.C.; Liu, D.D.; Jimenez, C.A.; Eapen, G.A.; Lotan, R.; Tang, X.; et al. Biological activity of celecoxib in the bronchial epithelium of current and former smokers. Cancer Prev. Res. 2010, 3, 148-159. [CrossRef]

84. Hansen-Petrik, M.B.; McEntee, M.F.; Jull, B.; Shi, H.; Zemel, M.B.; Whelan, J. Prostaglandin E2 protects intestinal tumors from nonsteroidal anti-inflammatory drug-induced regression in Apcmin/+ mice. Cancer Res. 2002, 62, 403-408. [PubMed]

85. Yan, M.; Myung, S.J.; Fink, S.P.; Lawrence, E.; Lutterbaugh, J.; Yang, P.; Zhou, X.; Liu, D.; Rerko, R.M.; Willis, J.; et al. 15-Hydroxyprostaglandin dehydrogenase inactivation as a mechanism of resistance to celecoxib chemoprevention of colon tumors. Proc. Natl. Acad. Sci. USA 2009, 106, 9409-9413. [CrossRef] [PubMed]

86. Myung, S.J.; Rerko, R.M.; Yan, M.; Platzer, P.; Guda, K.; Dotson, A.; Lawrence, E.; Dannenberg, A.J.; Lovgren, A.K.; Luo, G.; et al. 15-Hydroxyprostaglandin dehydrogenase is an in vivo suppressor of colon tumorigenesis. Proc. Natl. Acad. Sci. USA 2006, 103, 12098-12102. [CrossRef]

87. Kawamori, T.; Uchiya, N.; Sugimura, T.; Wakabayashi, K. Enhancement of colon carcinogenesis by prostaglandin E2 administration. Carcinogenesis 2003, 24, 985-990. [CrossRef] 
88. Rohwer, N.; Kühl, A.A.; Schebb, N.H.; Zopf, D.; Mcdonald, F.M.; Weylandt, K.-H. Effects of chronic low-dose aspirin treatment on tumor prevention in three mouse models of intestinal tumorigenesis. Cancer Med. 2020. [CrossRef]

89. Nakanishi, M.; Montrose, D.C.; Clark, P.; Nambiar, P.R.; Belinsky, G.S.; Claffey, K.P.; Xu, D.; Rosenberg, D.W. Genetic deletion of mPGES-1 suppresses intestinal tumorigenesis. Cancer Res. 2008, 68, 3251-3259. [CrossRef]

90. Nakanishi, M.; Menoret, A.; Tanaka, T.; Miyamoto, S.; Montrose, D.C.; Vella, A.T.; Rosenberg, D.W. Selective PGE 2 suppression inhibits colon carcinogenesis and modifies local mucosal immunity. Cancer Prev. Res. 2011, 4, 1198-1208. [CrossRef]

91. Sasaki, Y.; Nakatani, Y.; Hara, S. Role of microsomal prostaglandin E synthase-1 (mPGES-1)-derived prostaglandin E2 in colon carcinogenesis, Prostaglandins Other Lipid Mediat. Prostaglandins Other Lipid Mediat. 2015, 121, 42-45. [CrossRef] [PubMed]

92. Howe, L.R.; Subbaramaiah, K.; Kent, C.V.; Zhou, X.K.; Chang, S.H.; Hla, T.; Jakobsson, P.J.; Hudis, C.A.; Dannenberg, A.J. Genetic deletion of microsomal prostaglandin e synthase-1 suppresses mouse mammary tumor growth and angiogenesis. Prostaglandins Other Lipid Mediat. 2013, 106, 99-105. [CrossRef] [PubMed]

93. Finetti, F.; Terzuoli, E.; Bocci, E.; Coletta, I.; Polenzani, L.; Mangano, G.; Alisi, M.A.; Cazzolla, N.; Giachetti, A.; Ziche, M.; et al. Pharmacological inhibition of microsomal prostaglandin E synthase-1 suppresses epidermal growth factor receptor-mediated tumor growth and angiogenesis. PLoS ONE 2012, 7, e40576. [CrossRef] [PubMed]

94. Bergqvist, F.; Morgenstern, R.; Jakobsson, P.J. A review on mPGES-1 inhibitors: From preclinical studies to clinical applications. Prostaglandins Other Lipid Mediat. 2020, 147, 106383. [CrossRef] [PubMed]

95. Hanahan, D.; Weinberg, R.A. Hallmarks of cancer: The next generation. Cell 2011, 144, 646-674. [CrossRef] [PubMed]

96. Del Prete Annalisa, M.A. Allavena Paola, Santoro Giuseppe, Fumarulo Ruggiero, Corsi Massimi liano M, Infl ammation Mo le cu lar pat hways in can ce r-re la ted in $\mathrm{fl}$ am ma tion. Biochem. Medica 2011, 21, $264-275$.

97. Rajendran, P.; Chen, Y.F.; Chen, Y.F.; Chung, L.C.; Tamilselvi, S.; Shen, C.Y.; Day, C.H.; Chen, R.J.; Viswanadha, V.P.; Kuo, W.W.; et al. The multifaceted link between inflammation and human diseases. J. Cell Physiol. 2018, 233, 6458-6471. [CrossRef]

98. Wang, D.; Dubois, R.N. Prostaglandins and cancer. Gut 2006, 55, 115-122. [CrossRef]

99. Sugimoto, Y.; Narumiya, S. Prostaglandin E receptors. J. Biol. Chem. 2007, 282, 11613-11617. [CrossRef]

100. Watanabe, K.; Kawamori, T.; Nakatsugi, S.; Ohta, T.; Ohuchida, S.; Yamamoto, H.; Maruyama, T.; Kondo, K.; Ushikubi, F.; Narumiya, S.; et al. Role of the prostaglandin E receptor subtype EP1 in colon carcinogenesis. Cancer Res. 1999, 59, 5093-5096.

101. Watanabe, K.; Kawamori, T.; Nakatsugi, S.; Ohta, T.; Ohuchida, S.; Yamamoto, H.; Maruyama, T.; Kondo, K.; Narumiya, S.; Sugimura, T.; et al. Inhibitory effect of a prostaglandin E receptor subtype EP1 selective antagonist, ONO-8713, on development of azoxymethane-induced aberrant crypt foci in mice. Cancer Lett. 2000, 156, 57-61. [CrossRef]

102. Kawamori, T.; Kitamura, T.; Watanabe, K.; Uchiya, N.; Maruyama, T.; Narumiya, S.; Sugimura, T.; Wakabayashi, K. Prostaglandin E receptor subtype EP1 deficiency inhibits colon cancer development. Carcinogenesis 2005, 26, 353-357. [CrossRef] [PubMed]

103. Kitamura, T.; Itoh, M.; Noda, T.; Tani, K.; Kobayashi, M.; Maruyama, T.; Kobayashi, K.; Ohuchida, S.; Sugimura, T.; Wakabayashi, K. Combined effects of prostaglandin E receptor subtype EP1 and subtype EP4 antagonists on intestinal tumorigenesis in adenomatous polyposis coli gene knockout mice. Cancer Sci. 2003, 94, 618-621. [CrossRef] [PubMed]

104. Tober, K.L.; Wilgus, T.A.; Kusewitt, D.F.; Thomas-Ahner, J.M.; Maruyama, T.; Oberyszyn, T.M. Importance of the EP1 receptor in cutaneous UVB-induced inflammation and tumor development. J. Investig. Dermatol. 2006, 126, 205-211. [CrossRef] [PubMed]

105. Makita, H.; Mutoh, M.; Maruyama, T.; Yonemoto, K.; Kobayashi, A.; Fujitsuka, H.; Toida, M.; Shibata, T.; Miyamoto, S.; Yasui, Y.; et al. A prostaglandin E2 receptor subtype EP1-selective antagonist, ONO-8711, suppresses 4-nitroquinoline 1-oxide-induced rat tongue carcinogenesis. Carcinogenesis 2007, 28, 677-684. [CrossRef] [PubMed]

106. Narumiya, S.; Sugimoto, Y.; Ushikubi, F. Prostanoid receptors: Structures, properties, and functions. Physiol. Rev. 1999, 79, 1193-1226. [CrossRef] 
107. Castellone, M.D.; Teramoto, H.; Williams, B.O.; Druey, K.M.; Gutkind, J.S. Medicine: Prostaglandin E2 promotes colon cancer cell growth through a Gs-axin- $\beta$-catenin signaling axis. Science 2005, 310, 1504-1510. [CrossRef]

108. Kisslov, L.; Hadad, N.; Rosengraten, M.; Levy, R. HT-29 human colon cancer cell proliferation is regulated by cytosolic phospholipase A2 $\alpha$ dependent PGE2 via both PKA and PKB pathways. Biochim. Biophys. Acta Mol. Cell Biol. Lipids 2012, 1821, 1224-1234. [CrossRef]

109. Dufour, M.; Faes, S.; Dormond-Meuwly, A.; Demartines, N.; Dormond, O. PGE2-induced colon cancer growth is mediated by mTORC1. Biochem. Biophys. Res. Commun. 2014, 451, 587-591. [CrossRef]

110. Donnini, S.; Finetti, F.; Solito, R.; Terzuoli, E.; Sacchetti, A.; Morbidelli, L.; Patrignani, P.; Ziche, M. EP2 prostanoid receptor promotes squamous cell carcinoma growth through epidermal growth factor receptor transactivation and iNOS and ERK1/2 pathways. FASEB J. 2007, 21. [CrossRef]

111. Cui, F.B.; Huang, D.F.; Zhang, F.L.; Gao, E.Y.; Zhang, Y.; Cao, Y.M.; Ding, S.; Wang, Y.; Cao, Q.S.; Cao, X.M. Investigation on the regulatory effect of PGE2 on ESCC cells through the trans-activation of EGFR by EP2 and the relevant mechanism. Eur. Rev. Med. Pharmacol. Sci. 2017, 21, 5668-5676. [CrossRef] [PubMed]

112. Zang, S.; Ma, X.; Wu, Y.; Liu, W.; Cheng, H.; Li, J.; Liu, J.; Huang, A. PGE2 synthesis and signaling in malignant transformation and progression of human hepatocellular carcinoma. Hum. Pathol. 2017, 63, 120-127. [CrossRef] [PubMed]

113. Qiu, J.; Li, Q.; Bell, K.A.; Yao, X.; Du, Y.; Zhang, E.; Yu, J.J.; Yu, Y.; Shi, Z.; Jiang, J. Small-molecule inhibition of prostaglandin E receptor 2 impairs cyclooxygenase-associated malignant glioma growth. Br. J. Pharmacol. 2019, 176, 1680-1699. [CrossRef] [PubMed]

114. Xu, S.; Zhou, W.; Ge, J.; Zhang, Z. Prostaglandin E2 receptor EP4 is involved in the cell growth and invasion of Prostate cancer via the cAMP-PKA/PI3K-Akt signaling pathway. Mol. Med. Rep. 2018, 17, 4702-4712. [CrossRef] [PubMed]

115. Kashiwagi, E.; Inoue, S.; Mizushima, T.; Chen, J.; Ide, H.; Kawahara, T.; Reis, L.O.; Baras, A.S.; Netto, G.J.; Miyamoto, H. Prostaglandin receptors induce urothelial tumourigenesis as well as bladder cancer progression and cisplatin resistance presumably via modulating PTEN expression. Br. J. Cancer 2018, 118, $213-223$. [CrossRef]

116. Ke, J.; Yang, Y.; Che, Q.; Jiang, F.; Wang, H.; Chen, Z.; Zhu, M.; Tong, H.; Zhang, H.; Yan, X.; et al. Prostaglandin E2 (PGE2) promotes proliferation and invasion by enhancing SUMO-1 activity via EP4 receptor in endometrial cancer. Tumor Biol. 2016, 37, 12203-12211. [CrossRef]

117. Fredika, M.C. M Robertson 1, Ann-Marie Simeone, Abhijit Mazumdar, Ashish H Shah, John S McMurray, Sukhen Ghosh, Molecular and pharmacological blockade of the EP4 receptor selectively inhibits both proliferation and invasion of human inflammatory breast cancer cells-PubMed. J. Exp. Ther. Oncol. 2008, 7, 299-312.

118. Keith, R.L.; Geraci, M.W.; Nana-Sinkam, S.P.; Breyer, R.M.; Hudish, T.M.; Meyer, A.M.; Malkinson, A.M.; Dwyer-Nield, L.D. Prostaglandin E2 receptor subtype 2 (EP2) null mice are protected against murine lung tumorigenesis. Anticancer Res. 2006, 26, 2857-2861.

119. Sung, Y.M.; He, G.; Fischer, S.M. Lack of expression of the EP2 but not EP3 receptor for prostaglandin E2 results in suppression of skin tumor development. Cancer Res. 2005, 65, 9304-9311. [CrossRef]

120. Sung, Y.M.; He, G.; Hwang, D.H.; Fischer, S.M. Overexpression of the prostaglandin E2 receptor EP2 results in enhanced skin tumor development. Oncogene 2006, 25, 5507-5516. [CrossRef]

121. Chang, S.H.; Ai, Y.; Breyer, R.M.; Lane, T.F.; Hla, T. The prostaglandin e 2 receptor EP 2 is required for cyclooxygenase 2-mediated mammary hyperplasia. Cancer Res. 2005, 65, 4496-4499. [CrossRef] [PubMed]

122. Chang, S.H.; Liu, C.H.; Wu, M.T.; Hla, T. Regulation of vascular endothelial cell growth factor expression in mouse mammary tumor cells by the EP2 subtype of the prostaglandin E2 receptor. Prostaglandins Other Lipid Mediat. 2005, 76, 48-58. [CrossRef] [PubMed]

123. Sonoshita, M.; Takaku, K.; Sasaki, N.; Sugimoto, Y.; Ushikubi, F.; Narumiya, S.; Oshima, M.; Taketo, M.M. Acceleration of intestinal polyposis through prostaglandin receptor EP2 in Apc $\Delta 716$ knockout mice. Nat. Med. 2001, 7, 1048-1051. [CrossRef] [PubMed]

124. Mutoh, M.; Watanabe, K.; Kitamura, T.; Shoji, Y.; Takahashi, M.; Kawamori, T.; Sugimura, T.; Wakabayashi, K.; Tani, K.; Kobayashi, M.; et al. Involvement of prostaglandin E receptor subtype EP4 in colon carcinogenesis. Cancer Res. 2002, 62, 28-32. [PubMed] 
125. Ma, X.; Kundu, N.; Rifat, S.; Walser, T.; Fulton, A.M. Prostaglandin E receptor EP4 antagonism inhibits breast cancer metastasis. Cancer Res. 2006, 66, 2923-2927. [CrossRef] [PubMed]

126. Kotani, M.; Tanaka, I.; Ogawa, Y.; Usui, T.; Tamura, N.; Mori, K.; Narumiya, S.; Yoshimi, T.; Nakao, K. Structural organization of the human prostaglandin EP3 receptor subtype gene (PTGER3). Genomics 1997, 40, 425-434. [CrossRef]

127. Orie, N.N.; Clapp, L.H. Role of prostanoid IP and EP receptors in mediating vasorelaxant responses to PGI2 analogues in rat tail artery: Evidence for Gi/o modulation via EP3 receptors. Eur. J. Pharmacol. 2011, 654, 258-265. [CrossRef]

128. Ma, J.; Chen, M.; Xia, S.K.; Shu, W.; Guo, Y.; Wang, Y.H.; Xu, Y.; Bai, X.M.; Zhang, L.; Zhang, H.; et al. Prostaglandin E2 promotes liver cancer cell growth by the upregulation of FUSE-binding protein 1 expression. Int. J. Oncol. 2013, 42, 1093-1104. [CrossRef]

129. Bazzani, L.; Donnini, S.; Finetti, F.; Christofori, G.; Ziche, M. PGE2/EP3/SRC signaling induces EGFR nuclear translocation and growth through EGFR ligands release in lung adenocarcinoma cells. Oncotarget 2017, 8. [CrossRef]

130. Pai, R.; Soreghan, B.; Szabo, I.L.; Pavelka, M.; Baatar, D.; Tarnawski, A.S. Prostaglandin E2, transactivates EGF receptor: A novel mechanism for promoting colon cancer growth and gastrointestinal hypertrophy. Nat. Med. 2002, 8, 289-293. [CrossRef]

131. Buchanan, F.G.; Wang, D.; Bargiacchi, F.; DuBois, R.N. Prostaglandin E2 regulates cell migration via the intracellular activation of the epidermal growth factor receptor. J. Biol. Chem. 2003, 278, 35451-35457. [CrossRef] [PubMed]

132. Zhang, M.; Zhang, H.; Cheng, S.; Zhang, D.; Xu, Y.; Bai, X.; Xia, S.; Zhang, L.; Ma, J.; Du, M.; et al. Prostaglandin E2 accelerates invasion by upregulating Snail in hepatocellular carcinoma cells. Tumor Biol. 2014, 35, 7135-7145. [CrossRef] [PubMed]

133. Terzuoli, E.; Finetti, F.; Costanza, F.; Giachetti, A.; Ziche, M.; Donnini, S. Linking of mPGES-1 and iNOS activates stem-like phenotype in EGFR-driven epithelial tumor cells. Nitric Oxide Biol. Chem. 2017, 66. [CrossRef] [PubMed]

134. Donnini, S.; Finetti, F.; Terzuoli, E.; Giachetti, A.; Ĩiguez, M.A.; Hanaka, H.; Fresno, M.; Rådmark, O.; Ziche, M. EGFR signaling upregulates expression of microsomal prostaglandin e synthase- 1 in cancer cells leading to enhanced tumorigenicity. Oncogene 2012, 31. [CrossRef]

135. Terzuoli, E.; Donnini, S.; Giachetti, A.; Iñiguez, M.A.; Fresno, M.; Melillo, G.; Ziche, M. Inhibition of hypoxia inducible factor- $1 \alpha$ by dihydroxyphenylethanol, a product from olive oil, blocks microsomal prostaglandin-E synthase-1/vascular endothelial growth factor expression and reduces tumor angiogenesis. Clin. Cancer Res. 2010, 16, 4207-4216. [CrossRef]

136. Fukuda, R.; Kelly, B.; Semenza, G.L. Vascular endothelial growth factor gene expression in colon cancer cells exposed to prostaglandin E2 is mediated by hypoxia-inducible factor 1. Cancer Res. 2003, 63, 2330-2334.

137. Wang, X.; Klein, R.D. Prostaglandin E2 induces vascular endothelial growth factor secretion in prostate cancer cells through EP2 receptor-mediated cAMP pathway. Mol. Carcinog. 2007, 46, 912-923. [CrossRef]

138. Terzuoli, E.; Donnini, S.; Finetti, F.; Nesi, G.; Villari, D.; Hanaka, H.; Radmark, O.; Giachetti, A.; Ziche, M. Linking microsomal prostaglandin E Synthase-1/PGE-2 pathway with miR-15a and -186 expression: Novel mechanism of VEGF modulation in prostate cancer. Oncotarget 2016, 7. [CrossRef]

139. Spinella, F.; Rosanò, L.; di Castro, V.; Natali, P.G.; Bagnato, A. Endothelin-1-induced prostaglandin E3-EP2, EP4 signaling regulates vascular endothelial growth factor production and ovarian carcinoma cell invasion. J. Biol. Chem. 2004, 279, 46700-46705. [CrossRef]

140. Jain, S.; Chakraborty, G.; Raja, R.; Kale, S.; Kundu, G.C. Prostaglandin E2 regulates tumor angiogenesis in prostate cancer. Cancer Res. 2008, 68, 7750-7759. [CrossRef]

141. Madrigal-Martínez, A.; Fernández-Martínez, A.B.; Cazaña, F.J.L. Intracrine prostaglandin E2 pro-tumoral actions in prostate epithelial cells originate from non-canonical pathways. J. Cell. Physiol. 2018, 233, 3590-3602. [CrossRef] [PubMed]

142. Battersby, S.; Sales, K.J.; Williams, A.R.; Anderson, R.A.; Gardner, S.; Jabbour, H.N. Seminal plasma and prostaglandin E2 up-regulate fibroblast growth factor 2 expression in endometrial adenocarcinoma cells via E-series prostanoid-2 receptor-mediated transactivation of the epidermal growth factor receptor and extracellular signal-regulated kinase pathway. Hum. Reprod. 2007, 22, 36-44. [CrossRef] [PubMed] 
143. Salcedo, R.; Zhang, X.; Young, H.A.; Michael, N.; Wasserman, K.; Ma, W.H.; Martins-Green, M.; Murphy, W.J.; Oppenheim, J.J. Angiogenic effects of prostaglandin E2 are mediated by up-regulation of CXCR4 on human microvascular endothelial cells. Blood 2003, 102, 1966-1977. [CrossRef] [PubMed]

144. Inada, M.; Takita, M.; Yokoyama, S.; Watanabe, K.; Tominari, T.; Matsumoto, C.; Hirata, M.; Maru, Y.; Maruyama, T.; Sugimoto, Y.; et al. Direct melanoma cell contact induces stromal cell autocrine prostaglandin E2-EP4 receptor signaling that drives tumor growth, angiogenesis, and metastasis. J. Biol. Chem. 2015, 290, 29781-29793. [CrossRef]

145. Karpisheh, V.; Nikkhoo, A.; Hojjat-Farsangi, M.; Namdar, A.; Azizi, G.; Ghalamfarsa, G.; Sabz, G.; Yousefi, M.; Yousefi, B.; Jadidi-Niaragh, F. Prostaglandin E2 as a potent therapeutic target for treatment of colon cancer. Prostaglandins Other Lipid Mediat. 2019, 144. [CrossRef]

146. Aoki, T.; Narumiya, S. Prostaglandin E2-EP2 signaling as a node of chronic inflammation in the colon tumor microenvironment. Inflamm. Regen. 2017, 37. [CrossRef]

147. Kamiyama, M.; Pozzi, A.; Yang, L.; DeBusk, L.M.; Breyer, R.M.; Lin, P.C. EP2, a receptor for PGE2, regulates tumor angiogenesis through direct effects on endothelial cell motility and survival. Oncogene 2006, 25, 7019-7028. [CrossRef]

148. Amano, H.; Hayashi, I.; Endo, H.; Kitasato, H.; Yamashina, S.; Maruyama, T.; Kobayashi, M.; Satoh, K.; Narita, M.; Sugimoto, Y.; et al. Host prostaglandin E2-EP3 signaling regulates tumor-associated angiogenesis and tumor growth. J. Exp. Med. 2003, 197, 221-232. [CrossRef]

149. Finetti, F.; Solito, R.; Morbidelli, L.; Giachetti, A.; Ziche, M.; Donnini, S. Prostaglandin $E_{2}$ Regulates Angiogenesis via Activation of Fibroblast Growth Factor Receptor-1. J. Biol. Chem. 2008, 283, 2139-2146. [CrossRef]

150. Finetti, F.; Donnini, S.; Giachetti, A.; Morbidelli, L.; Ziche, M. Prostaglandin E2 primes the angiogenic switch via a synergic interaction with the fibroblast growth factor-2 pathway. Circ. Res. 2009, 105. [CrossRef]

151. Liu, S.; Jiang, M.; Zhao, Q.; Li, S.; Peng, Y.; Zhang, P.; Han, M. Vascular endothelial growth factor plays a critical role in the formation of the pre-metastatic niche via prostaglandin E2. Oncol. Rep. 2014, 32, 2477-2484. [CrossRef] [PubMed]

152. Wang, T.; Jing, B.; Sun, B.; Liao, Y.; Song, H.; Xu, D.; Guo, W.; Li, K.; Hu, M.; Liu, S.; et al. Stabilization of PTGES by deubiquitinase USP9X promotes metastatic features of lung cancer via PGE2 signaling. Am. J. Cancer Res. 2019, 9, 1145-1160. [PubMed]

153. Wang, D.; Fu, L.; Sun, H.; Guo, L.; Dubois, R.N. Prostaglandin E2 Promotes Colorectal Cancer Stem Cell Expansion and Metastasis in Mice. Gastroenterology 2015, 149, 1884-1895.e4. [CrossRef] [PubMed]

154. Cen, B.; Lang, J.D.; Du, Y.; Wei, J.; Xiong, Y.; Bradley, N.; Wang, D.; DuBois, R.N. Prostaglandin E2 Induces miR675-5p to Promote Colorectal Tumor Metastasis via Modulation of p53 Expression. Gastroenterology 2020, 158, 971-984.e10. [CrossRef]

155. Li, S.; Xu, X.; Jiang, M.; Bi, Y.; Xu, J.; Han, M. Lipopolysaccharide induces inflammation and facilitates lung metastasis in a breast cancer model via the prostaglandin E2-EP2 pathway. Mol. Med. Rep. 2015, 11, 4454-4462. [CrossRef]

156. Watanabe, Y.; Imanishi, Y.; Ozawa, H.; Sakamoto, K.; Fujii, R.; Shigetomi, S.; Habu, N.; Otsuka, K.; Sato, Y.; Sekimizu, M.; et al. Selective EP2 and Cox-2 inhibition suppresses cell migration by reversing epithelial-to-mesenchymal transition and Cox-2 overexpression and E-cadherin downregulation are implicated in neck metastasis of hypopharyngeal cancer. Am. J. Transl. Res. 2020, 12, 1096-1113.

157. Topalian, S.L.; Taube, J.M.; Anders, R.A.; Pardoll, D.M. Mechanism-driven biomarkers to guide immune checkpoint blockade in cancer therapy. Nat. Rev. Cancer 2016. [CrossRef]

158. Condamine, T.; Gabrilovich, D.I. Molecular mechanisms regulating myeloid-derived suppressor cell differentiation and function. Trends Immunol. 2011, 32, 19-25. [CrossRef]

159. Travelli, C.; Consonni, F.M.; Sangaletti, S.; Storto, M.; Morlacchi, S.; Grolla, A.A.; Galli, U.; Tron, G.C.; Portararo, P.; Rimassa, L.; et al. Nicotinamide phosphoribosyltransferase acts as a metabolic gate for mobilization of myeloid-derived suppressor cells. Cancer Res. 2019, 79, 1938-1951. [CrossRef]

160. Porta, C.; Consonni, F.M.; Morlacchi, S.; Sangaletti, S.; Bleve, A.; Totaro, M.G.; Larghi, P.; Rimoldi, M.; Tripodo, C.; Strauss, L.; et al. Tumor-Derived Prostaglandin E2 Promotes p50 NF-kB-Dependent Differentiation of Monocytic MDSCs. Cancer Res. 2020, 80, 2874-2888. [CrossRef]

161. Sinha, P.; Clements, V.K.; Fulton, A.M.; Ostrand-Rosenberg, S. Prostaglandin E2 promotes tumor progression by inducing myeloid-derived suppressor cells. Cancer Res. 2007, 67, 4507-4513. [CrossRef] [PubMed] 
162. Yu, S.; Liu, C.; Su, K.; Wang, J.; Liu, Y.; Zhang, L.; Li, C.; Cong, Y.; Kimberly, R.; Grizzle, W.E.; et al. Tumor Exosomes Inhibit Differentiation of Bone Marrow Dendritic Cells. J. Immunol. 2007. [CrossRef] [PubMed]

163. Xiang, X.; Poliakov, A.; Liu, C.; Liu, Y.; Deng, Z.B.; Wang, J.; Cheng, Z.; Shah, S.V.; Wang, G.J.; Zhang, L.; et al. Induction of myeloid-derived suppressor cells by tumor exosomes. Int. J. Cancer 2009, 124, 2621-2633. [CrossRef] [PubMed]

164. Obermajer, N.; Muthuswamy, R.; Lesnock, J.; Edwards, R.P.; Kalinski, P. Positive feedback between PGE2 and COX2 redirects the differentiation of human dendritic cells toward stable myeloid-derived suppressor cells. Blood 2011, 118, 5498-5505. [CrossRef] [PubMed]

165. Obermajer, N.; Kalinski, P. Generation of myeloid-derived suppressor cells using prostaglandin E2. Transplant. Res. 2012, 1, 2-7. [CrossRef]

166. Rodríguez-Ubreva, J.; Català-Moll, F.; Obermajer, N.; Álvarez-Errico, D.; Ramirez, R.N.; Company, C.; Vento-Tormo, R.; Moreno-Bueno, G.; Edwards, R.P.; Mortazavi, A.; et al. Prostaglandin E2 Leads to the Acquisition of DNMT3A-Dependent Tolerogenic Functions in Human Myeloid-Derived Suppressor Cells. Cell Rep. 2017, 21, 154-167. [CrossRef]

167. Mao, Y.; Sarhan, D.; Steven, A.; Seliger, B.; Kiessling, R.; Lundqvist, A. Inhibition of tumor-derived prostaglandin-E2 blocks the induction of myeloid-derived suppressor cells and recovers natural killer cell activity. Clin. Cancer Res. 2014, 20, 4096-4106. [CrossRef]

168. Fujita, M.; Kohanbash, G.; Fellows-Mayle, W.; Hamilton, R.L.; Komohara, Y.; Decker, S.A.; Ohlfest, J.R.; Okada, H. COX-2 blockade suppresses gliomagenesis by inhibiting myeloid-derived suppressor cells. Cancer Res. 2011, 71, 2664-2674. [CrossRef]

169. Yang, F.; Wei, Y.; Cai, Z.; Yu, L.; Jiang, L.; Zhang, C.; Yan, H.; Wang, Q.; Cao, X.; Liang, T.; et al. Activated cytotoxic lymphocytes promote tumor progression by increasing the ability of $3 \mathrm{LL}$ tumor cells to mediate MDSC chemoattraction via Fas signaling. Cell. Mol. Immunol. 2015, 12, 66-76. [CrossRef]

170. Gabrilovich, D.I. Myeloid-derived suppressor cells. Cancer Immunol. Res. 2017. [CrossRef]

171. Ochoa, A.C.; Zea, A.H.; Hernandez, C.; Rodriguez, P.C. Arginase, Prostaglandins, and Myeloid-Derived Suppressor Cells in Renal Cell Carcinoma. Clin. Cancer Res. 2007. [CrossRef] [PubMed]

172. Mao, Y.; Poschke, I.; Wennerberg, E.; de Coaña, Y.P.; Brage, S.E.; Schultz, I.; Hansson, J.; Masucci, G.; Lundqvist, A.; Kiessling, R. Melanoma-educated CD14+ cells acquire a myeloid-derived suppressor cell phenotype through COX-2-dependent mechanisms. Cancer Res. 2013, 73, 3877-3887. [CrossRef] [PubMed]

173. Kuroda, H.; Mabuchi, S.; Yokoi, E.; Komura, N.; Kozasa, K.; Matsumoto, Y.; Kawano, M.; Takahashi, R.; Sasano, T.; Shimura, K.; et al. Prostaglandin E2 produced by myeloid-derived suppressive cells induces cancer stem cells in uterine cervical cancer. Oncotarget 2018, 9, 36317-36330. [CrossRef] [PubMed]

174. Komura, N.; Mabuchi, S.; Shimura, K.; Yokoi, E.; Kozasa, K.; Kuroda, H.; Takahashi, R.; Sasano, T.; Kawano, M.; Matsumoto, Y.; et al. The role of myeloid-derived suppressor cells in increasing cancer stem-like cells and promoting PD-L1 expression in epithelial ovarian cancer. Cancer Immunol. Immunother. 2020. [CrossRef]

175. Hou, W.; Sampath, P.; Rojas, J.J.; Thorne, S.H. Oncolytic Virus-Mediated Targeting of PGE2 in the Tumor Alters the Immune Status and Sensitizes Established and Resistant Tumors to Immunotherapy. Cancer Cell. 2016. [CrossRef]

176. Yin, J.; Kim, S.S.; Choi, E.; Oh, Y.T.; Lin, W.; Kim, T.H.; Sa, J.K.; Hong, J.H.; Park, S.H.; Kwon, H.J.; et al. ARS2/MAGL signaling in glioblastoma stem cells promotes self-renewal and M2-like polarization of tumor-associated macrophages. Nat. Commun. 2020, 11. [CrossRef]

177. Chang, J.; Vacher, J.; Yao, B.; Fan, X.; Zhang, B.; Harris, R.C.; Zhang, M.Z. Prostaglandin E receptor 4 (EP4) promotes colonic tumorigenesis. Oncotarget 2015, 6, 33500-33511. [CrossRef]

178. Heusinkveld, M.; van Steenwijk, P.J.d.; Goedemans, R.; Ramwadhdoebe, T.H.; Gorter, A.; Welters, M.J.P.; van Hall, T.; van der Burg, S.H. M2 Macrophages Induced by Prostaglandin E 2 and IL-6 from Cervical Carcinoma Are Switched to Activated M1 Macrophages by CD4 + Th1 Cells. J. Immunol. 2011, 187, 1157-1165. [CrossRef]

179. Oshima, H.; Hioki, K.; Popivanova, B.K.; Oguma, K.; van Rooijen, N.; Ishikawa, T.; Oshima, M. Prostaglandin E2 2 signaling and bacterial infection recruit tumor-promoting macrophages to mouse gastric tumors. Gastroenterology 2011, 140, 596-607.e7. [CrossRef] 
180. Prima, V.; Kaliberova, L.N.; Kaliberov, S.; Curiel, D.T.; Kusmartsev, S. COX2/mPGES1/PGE2 pathway regulates PD-L1 expression in tumor-associated macrophages and myeloid-derived suppressor cells. Proc. Natl. Acad. Sci. USA 2017, 114, 1117-1122. [CrossRef]

181. Huang, L.; Nakamura, Y.; Lo, E.H.; Hayakawa, K. Astrocyte Signaling in the Neurovascular Unit After Central Nervous System Injury. Int. J. Mol. Sci. 2019, 20, 282. [CrossRef] [PubMed]

182. Waisman, A. Dendritic cells as gatekeepers of tolerance. Semin. Immunopathol. Vol. 2017, 39, 153-163. [CrossRef] [PubMed]

183. Böttcher, J.P.; Bonavita, E.; Chakravarty, P.; Blees, H.; Cabeza-Cabrerizo, M.; Sammicheli, S.; Rogers, N.C.; Sahai, E.; Zelenay, S.; e Sousa, C.R. NK Cells Stimulate Recruitment of cDC1 into the Tumor Microenvironment Promoting Cancer Immune Control. Cell 2018, 172, 1022-1037.e14. [CrossRef] [PubMed]

184. Ogawa, F.; Amano, H.; Eshima, K.; Ito, Y.; Matsui, Y.; Hosono, K.; Kitasato, H.; Iyoda, A.; Iwabuchi, K.; Kumagai, Y.; et al. Prostanoid induces premetastatic niche in regional lymph nodes. J. Clin. Investig. 2014, 124, 4882-4894. [CrossRef] [PubMed]

185. Youlin, K.; Weiyang, H.; Simin, L.; Xin, G. Prostaglandin E 2 Inhibits Prostate Cancer Progression by Countervailing Tumor Microenvironment-Induced Impairment of Dendritic Cell Migration through LXR a/CCR7 Pathway. J. Immunol. Res. 2018, 2018, 5808962. [CrossRef] [PubMed]

186. Caligiuri, M.A. Human natural killer cells. Blood 2008, 112, 461-469. [CrossRef]

187. Fruci, D.; Monaco, E.L.; Cifaldi, L.; Locatelli, F.; Tremante, E.; Benevolo, M.; Giacomini, P. T and NK cells: Two sides of tumor immunoevasion. J. Transl. Med. 2013, 11, 30. [CrossRef]

188. Fulton, A.M.; Chong, Y.C. Prostaglandin E2 receptor activity and susceptibility to natural killer cells. J. Leukoc. Biol. 1992, 51, 176-180. [CrossRef]

189. Martinet, L.; Jean, C.; Dietrich, G.; Fournié, J.J.; Poupot, R. PGE2 inhibits natural killer and $\gamma \delta \mathrm{T}$ cell cytotoxicity triggered by NKR and TCR through a cAMP-mediated PKA type I-dependent signaling. Biochem. Pharmacol. 2010, 80, 838-845. [CrossRef]

190. Pietra, G.; Manzini, C.; Rivara, S.; Vitale, M.; Cantoni, C.; Petretto, A.; Balsamo, M.; Conte, R.; Benelli, R.; Minghelli, S.; et al. Melanoma cells inhibit natural killer cell function by modulating the expression of activating receptors and cytolytic activity. Cancer Res. 2012, 72, 1407-1415. [CrossRef]

191. Asghar, K.; Farooq, A.; Zulfiqar, B.; Rashid, M.U. Indoleamine 2,3-dioxygenase: As a potential prognostic marker and immunotherapeutic target for hepatocellular carcinoma. World J. Gastroenterol. 2017, 23, 2286-2293. [CrossRef] [PubMed]

192. Park, A.; Lee, Y.; Kim, M.S.; Kang, Y.J.; Park, Y.J.; Jung, H.; Kim, T.D.; Lee, H.G.; Choi, I.; Yoon, S.R. Prostaglandin E2 secreted by thyroid cancer cells contributes to immune escape through the suppression of natural killer (NK) cell cytotoxicity and NK cell differentiation. Front. Immunol. 2018, 9, 1859. [CrossRef] [PubMed]

193. Li, T.; Yi, S.; Liu, W.; Jia, C.; Wang, G.; Hua, X.; Tai, Y.; Zhang, Q.; Chen, G. Colorectal carcinoma-derived fibroblasts modulate natural killer cell phenotype and antitumor cytotoxicity. Med. Oncol. 2013, 30. [CrossRef]

194. Holt, D.M.; Ma, X.; Kundu, N.; Collin, P.D.; Fulton, A.M. Modulation of Host Natural Killer Cell Functions in Breast Cancer via Prostaglandin E2 Receptors EP2 and EP4. J. Immunother. 2012, 35, 179-188. [CrossRef]

195. Holt, D.; Ma, X.; Kundu, N.; Fulton, A. Prostaglandin E2 (PGE2) suppresses natural killer cell function primarily through the PGE2 receptor EP4. Cancer Immunol. Immunother. 2011, 60, 1577-1586. [CrossRef]

196. Kundu, N.; Ma, X.; Holt, D.; Goloubeva, O.; Ostrand-Rosenberg, S.; Fulton, A.M. Antagonism of the prostaglandin E receptor EP4 inhibits metastasis and enhances NK function. Breast Cancer Res. Treat. 2009, 117, 235-242. [CrossRef]

197. Ma, X.; Holt, D.; Kundu, N.; Reader, J.; Goloubeva, O.; Take, Y.; Fulton, A.M. A prostaglandin E (PGE) receptor EP4 antagonist protects natural killer cells from PGE2-mediated immunosuppression and inhibits breast cancer metastasis. Oncoimmunology 2013, 2, e22647. [CrossRef]

198. Harizi, H. Reciprocal crosstalk between dendritic cells and natural killer cells under the effects of PGE2 in immunity and immunopathology. Cell. Mol. Immunol. 2013, 10, 213-221. [CrossRef]

199. Kondo, M. One Niche to Rule Both Maintenance and Loss of Stemness in HSCs. Immunity 2016, 45, 1177-1179. [CrossRef] 
200. Shimabukuro-Vornhagen, A.; Liebig, T.M.; Koslowsky, T.; Theurich, S.; von Bergwelt-Baildon, M.S. The ratio between dendritic cells and T cells determines whether prostaglandin $\mathrm{E} 2$ has a stimulatory or inhibitory effect. Cell. Immunol. 2013, 281, 62-67. [CrossRef]

201. Basingab, F.S.; Ahmadi, M.; Morgan, D.J. IFNg-Dependent Interactions between ICAM-1 and LFA-1 counteract prostaglandin E2-mediated inhibition of antitumor CTL responses. Cancer Immunol. Res. 2016, 4, 400-411. [CrossRef] [PubMed]

202. Hennequart, M.; Pilotte, L.; Cane, S.; Hoffmann, D.; Stroobant, V.; de Plaen, E.; van den Eynde, B.J. Constitutive IDO1 expression in human tumors is driven by cyclooxygenase-2 and mediates intrinsic immune resistance. Cancer Immunol. Res. 2017, 5, 695-709. [CrossRef] [PubMed]

203. Sharma, S.; Yang, S.C.; Zhu, L.; Reckamp, K.; Gardner, B.; Baratelli, F.; Huang, M.; Batra, R.K.; Dubinett, S.M. Tumor cyclooxygenase-2/prostaglandin E2-dependent promotion of FOXP3 expression and CD4+CD25+ T regulatory cell activities in lung cancer. Cancer Res. 2005, 65, 5211-5220. [CrossRef] [PubMed]

204. Kim, I.K.; Koh, C.H.; Jeon, I.; Shin, K.S.; Kang, T.S.; Bae, E.A.; Seo, H.; Ko, H.J.; Kim, B.S.; Chung, Y.; et al. GM-CSF promotes antitumor immunity by inducing Th9 cell responses. Cancer Immunol. Res. 2019, 7, 498-509. [CrossRef]

205. Yu, M.; Guo, G.; Zhang, X.; Li, L.; Yang, W.; Bollag, R.; Cui, Y. Fibroblastic reticular cells of the lymphoid tissues modulate $\mathrm{T}$ cell activation threshold during homeostasis via hyperactive cyclooxygenase-2/prostaglandin E2 axis. Sci. Rep. 2017, 7, 3350. [CrossRef] [PubMed]

206. Gorchs, L.; Moro, C.F.; Bankhead, P.; Kern, K.P.; Sadeak, I.; Meng, Q.; Rangelova, E.; Kaipe, H. Human pancreatic carcinoma-associated fibroblasts promote expression of co-inhibitory markers on CD4+ and CD8+ T-cells. Front. Immunol. 2019, 10. [CrossRef]

207. Mizuno, R.; Kawada, K.; Sakai, Y. Prostaglandin E2/EP signaling in the tumor microenvironment of colorectal cancer. Int. J. Mol. Sci. 2019, 20, 6254. [CrossRef]

Publisher's Note: MDPI stays neutral with regard to jurisdictional claims in published maps and institutional affiliations.

(C) 2020 by the authors. Licensee MDPI, Basel, Switzerland. This article is an open access article distributed under the terms and conditions of the Creative Commons Attribution (CC BY) license (http://creativecommons.org/licenses/by/4.0/). 